\title{
جمالية النسق التعبدي في الكون، أو موسيقى الكائنات من منظور النورسي: دراسة في الكليات'
}

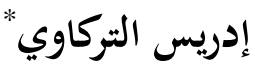

\author{
الملخص \\ للكائنات في تأملات النورسي وظيفة موسيقية جمالية في الكون، تتشكَّل من حركاتما المادية وتسبيحامًا الروحية،

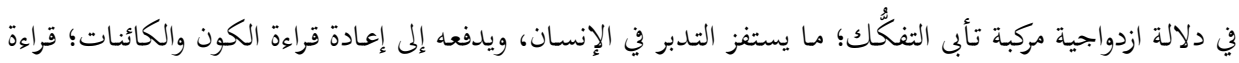

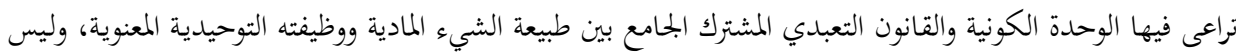

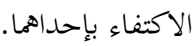 \\ الكلمات المفتاحية: النورسي، النسق التعبدي، الجمال، الموسيقى، الكليات.
}

\section{Aesthetic Worship Pattern in the Cosmos, or "Music of Creatures" from Nursi's Perspective: A Study of the Universals}

\begin{abstract}
Nursi's reflections show that creatures have an aesthetic musical function which is composed of their physical movement and spiritual glorification, which comes in inseparable compound duality. This function provokes human contemplation that requires rereading the natural cosmos and creatures in such a way that takes into account the cosmos unity and the common worship law which bring together both the physical nature of things and their moral monotheistic function.
\end{abstract}

Keywords: Sa'id Nursi, Worship patterns, Beauty, Music, Universals.

$$
\begin{aligned}
& \text { ' الكليات بمعناها المصدري لا بعتناها الاسمي، فليس المقصود كليات رسائل النور بوصفها علماً على الكتاب، وإنَّا }
\end{aligned}
$$

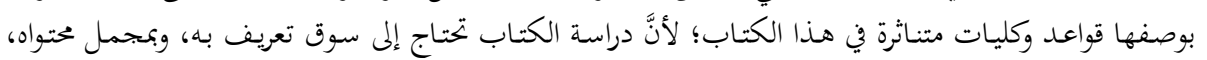

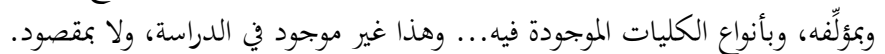

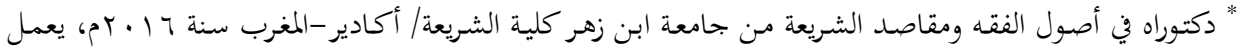

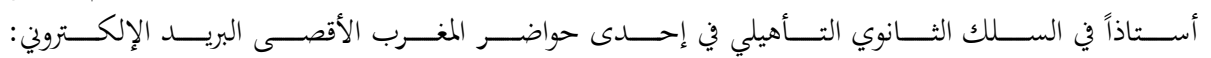

$$
\begin{aligned}
& \text { driss_tar@hotmail.com }
\end{aligned}
$$

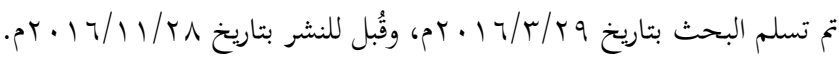


لو شئنا كشف حقيقة الإنسان لقلنا إنَّهَ مادة ونور، أو نفس وروح. وحيث قُدِّرَ أنْ

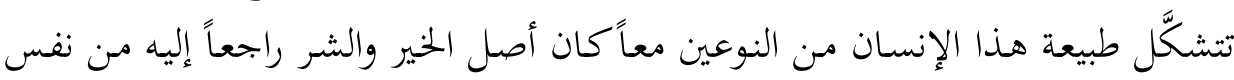

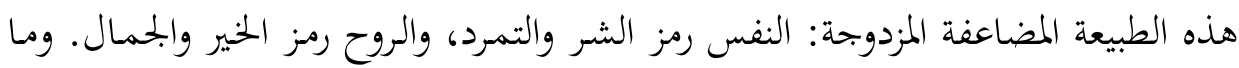

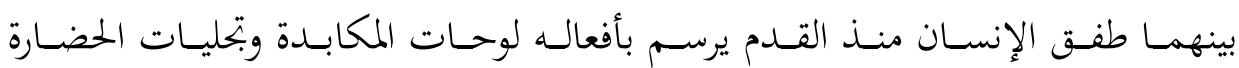

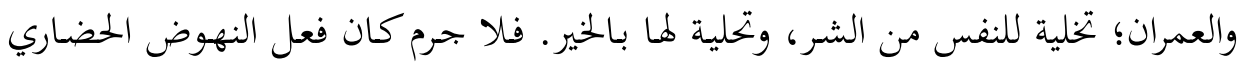

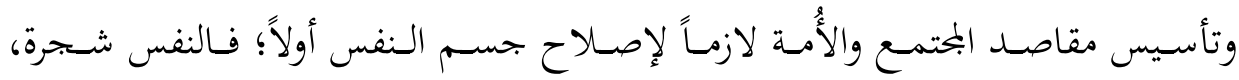

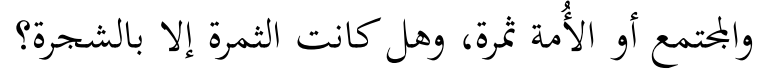

وقد كان نور القرآن هو ماء الحياة في هذه الشجرة، ومُناخها الجميل الذي يعيد لها

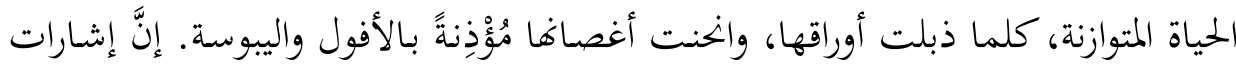

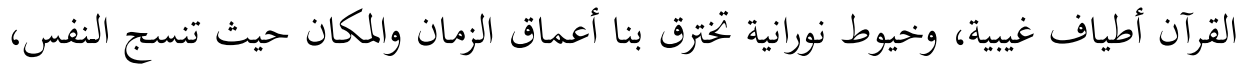

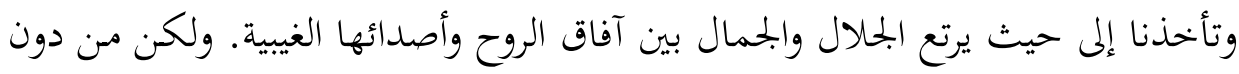

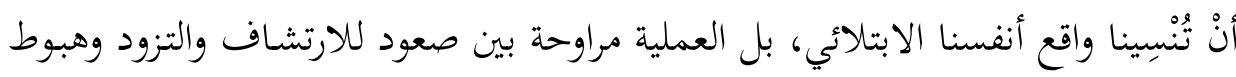

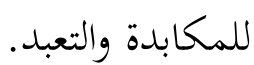

إنَّ الدخول في فضاءات القرآن معناه استشراف تلك الأصداء، واستمطار أندائها

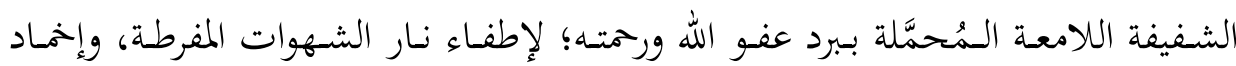

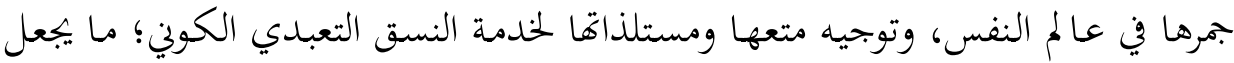

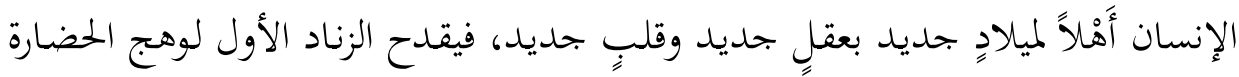

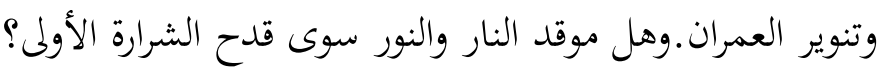
كهذا المعنى، فقد غدا الكون لازماً ضرورياً لنفس الإنسان؛ لأنَّه -بكائناته وطيباته-

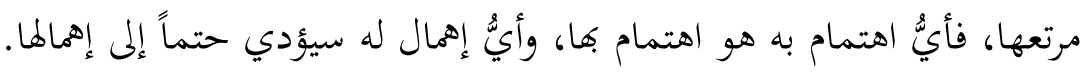
وتبعاً لهذه العلاقة العضوية الضرورية، لم يعد الكون في منظور النورسي طبيعة جامدة

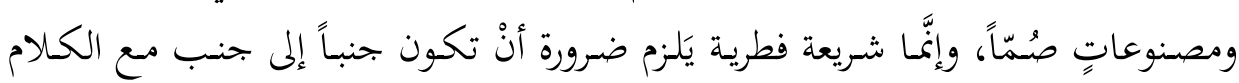




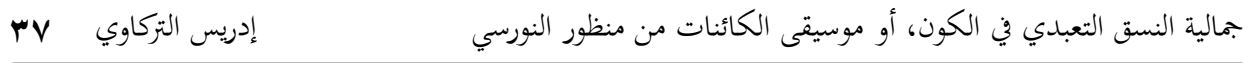

الإلهي؛ إذ كلاهما مُطلَق، وهل القرآن إلا معادل موضوعي للكون، وفهرسة بيانية لجواهر

الكائنات وأعراضها؟ إلإن

الـنفس والكــون والـوحي؛ كلهـا كانست أتـافي بنـاء الحضــارة في منظومسة النورسي

الإصلاحية، وهي بحالاهـا في الوقت نفسه. وحيث كانت نظرته عميقـة عمق كل نظرة

بُحُدِّدٍ ديني إلى العالم، كانت نتائج الحراك الإصلاحي بين هذه الأثافي الثلاثة أعمق مـن

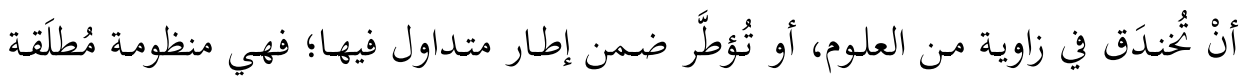

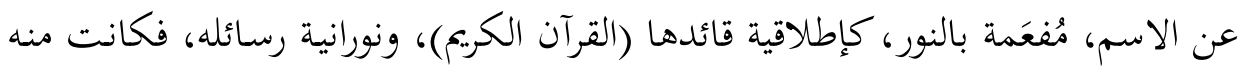
وإليه. فلا عجب أنْ خطفت -حتى في لقبها- صفة منه (كليات رسائل النور)، ترميزاً

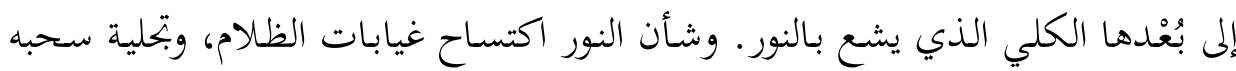

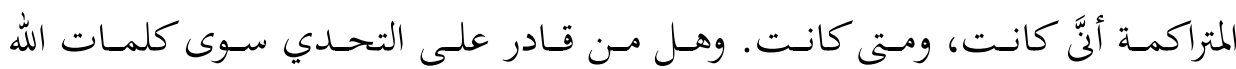
المُحمَّلة بنور الماوراء؟

تأسيساً على ذلك كله، انطلق عملاق الأناضول في سياحة قلبية كونية للتفاعل مع الكائنات، واستقراء وظائفها؛ قصْد إنشاء مُدوَّنة من الإبداع الجمالي والإصلاح العلمي والحضاري بصورة لم تكن معهودة عند مَن كان قبله، ولا خطتَّها أيمافهم.

نحاول في هذه الجولة الكشف عن أسرار علاقة النورسي النفسية بالكون، والوقوف مـع منطقـه الوجــاتي في ارتباطه بالكائنـات، بوصفها يخلوقـات تتعبـد بـالطبع والوظيفـة، وليس فقط مصنوعات مادية، أو أشياء جامدة. ولقد فاض من نسقها التكويني التعبدي مشاهد جمالية ولوحات فنية، كان لصداها في وجدان بـديع الزمان انعكاس تصويتي في صورة ترنيمات وألوان وإيقاعات وحركات... فكانت (موسيقى الكائنات). فما دلالة موسيقى الكائنات عند بلديع الزمان؟ وما وجه ارتباطها بمنظومة الجمال

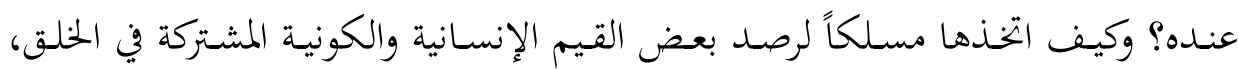
وكذا دحض قوانين الطبيعة الجامدة كما في الفلسفة المادية؟ 


\section{أولاً: مشاهد ترتُبّ الجمال، وتكوين أصل النسق التعبدي}

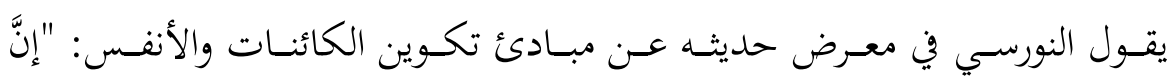

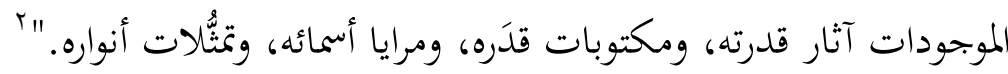

تُعُلُّه هذه القاعدة التعريفية بالكائنات - في الرسائل كلها - أهم كلية مختصرة تنسيقية

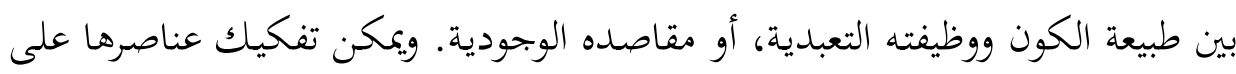

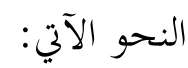

$$
\text { الموجودات (الكائنات) }
$$

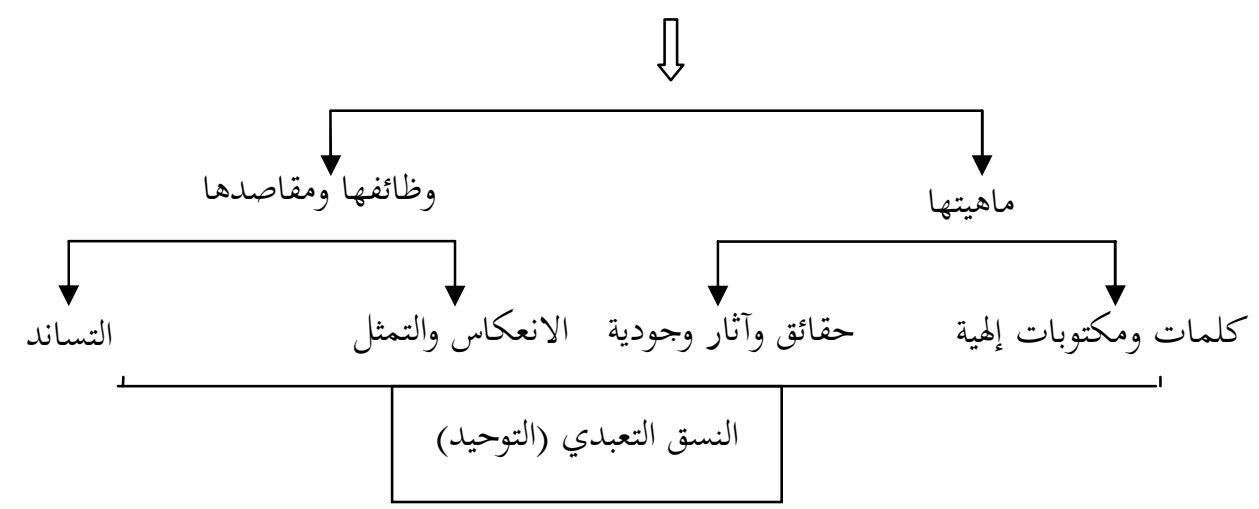

\section{1 ا ـ مشهد تشخُُص الكلمات:}

تبدو حقيقة الأشياء عند النورسي كلمات ومكتوبات في علم الله ومشيئته التكوينية،

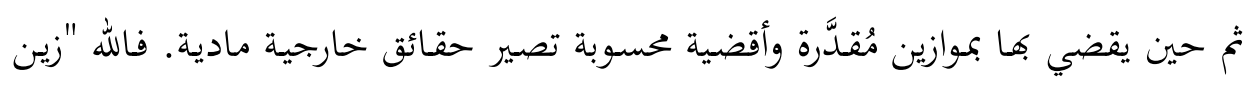

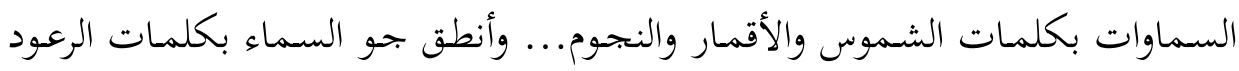

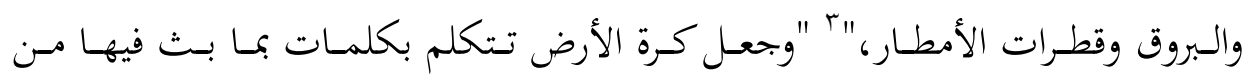

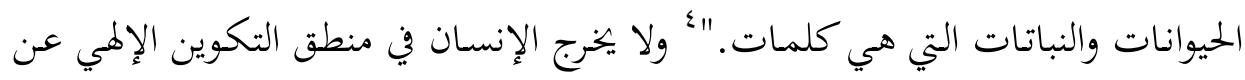

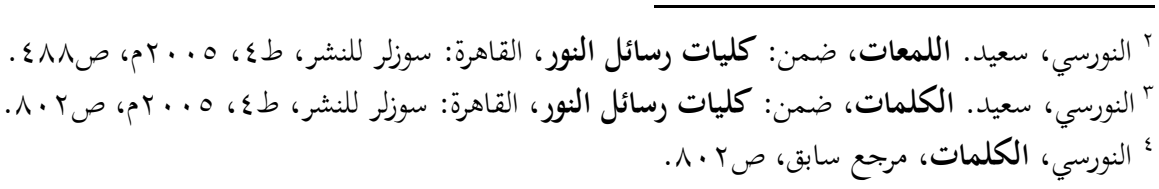


النسق. "حسبي من الحياة ووظيفتها كوني ككلمة مكتوبة بقلم القدرة، ومفهومة دالة على أسماء القدير المطلق."

فالكلمات في بُعْدها القرآني أسماء محفوظة، ثم تتشخَّص وتتكوَّن في الوجود في صورة

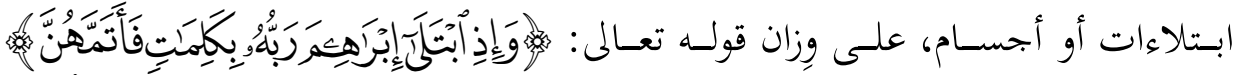

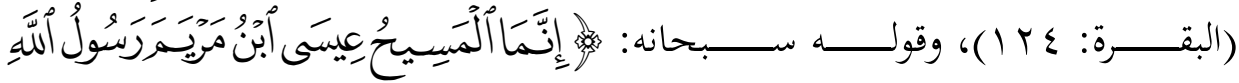

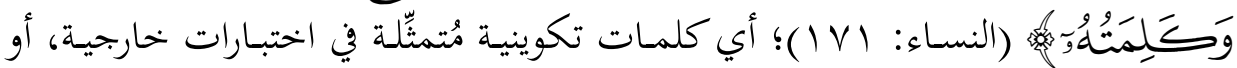

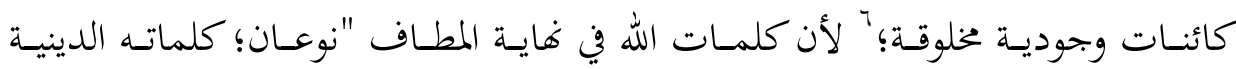

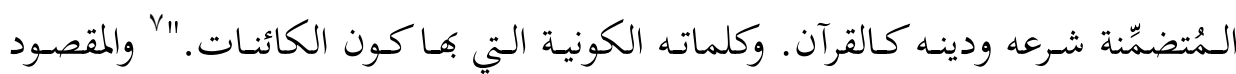
بالأصالة عند النورسي هذه الثانية؛ أي التكوينية، وليس التشريعية الخاصة، وسنُبيّنِ ذلك ولك

$$
\text { من بحموع نصوصه فيما بعلُ بصورة أوضح. }
$$

وبهـذين البُعْدين (أي التكـوين، والتمشُّل) راح النورسي يرسـم صسورة تعبديـة نسـقية

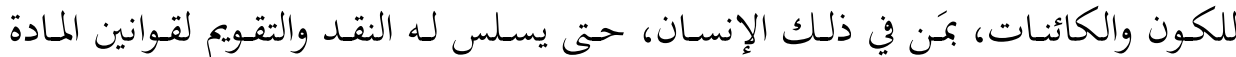

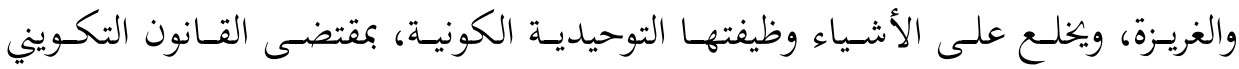

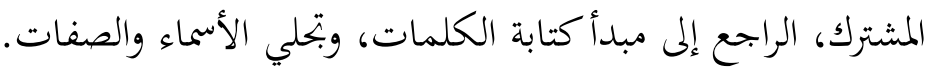

\section{Y. ب مشهد تجلي الأسماء والصفات:}

يُعَدُُّ مشـهـد الأسمـاء والصفات في تكوين المخلوقات وفلسفة القضـاء والقـدر أحسد

أعظم المشاهد الإلهية في الكون. يقول ابن القيِّم في ذلك: "وهو من أجلِّ المشاهد (...)

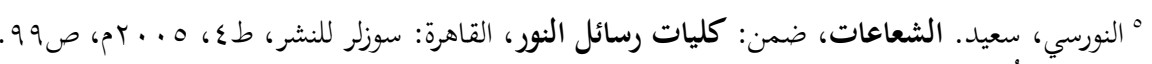

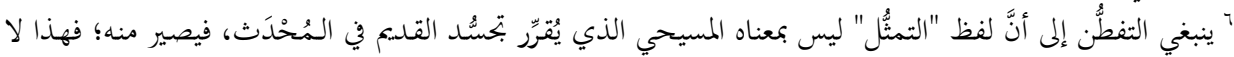

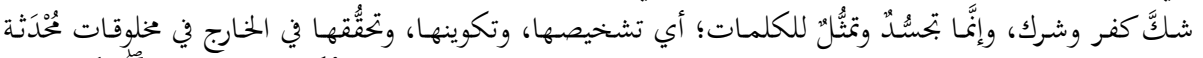

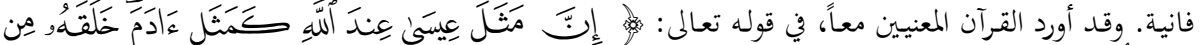

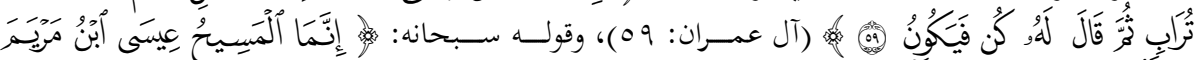

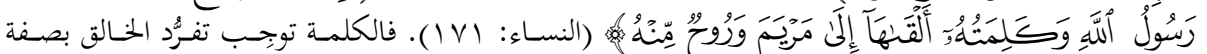

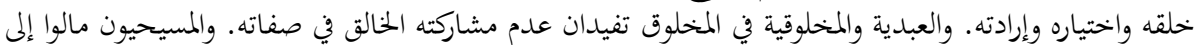

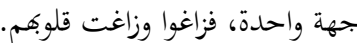

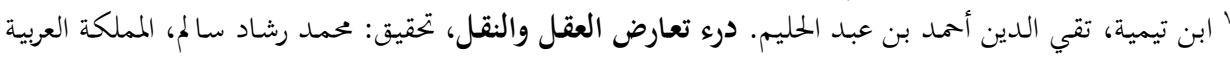

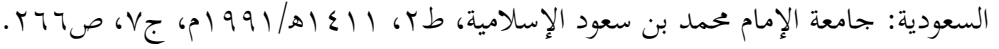




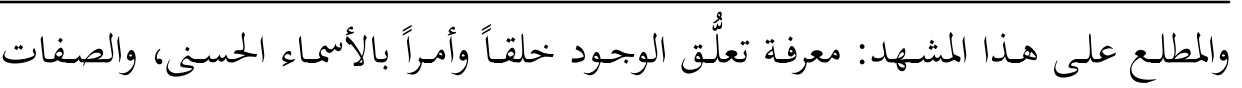

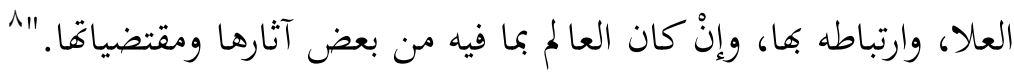

فبمقتضى هذا المشهـد يشترك الإنسان مع الكون، ويتساوى الحقير مع العظيم في

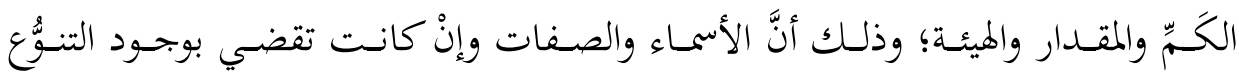
والتكاثر والتفاوت؛ "لأن الأسماء في الكون متداخل بعضها في بعض كالدوائر المتداخلة،

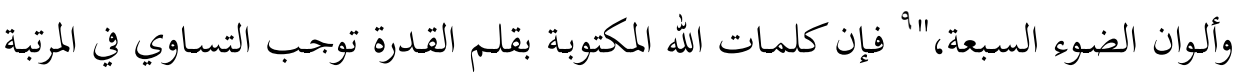
بين هذه الكائنات بالنسبة إليها؛ إذ "لا مراتب في تلك القدرة، فتتساوى بالنسبة إليها الذرات والنجوم والقليل والكثير." ·' وذلك حتى يكون الاهتمام بالذرة بالنسبة إلى القدرة كالاهتمام بالبحرة في الإعجاز . ك ولئ.

ولا شــكَّ في أن هـــا التبـاين في الماهيـات والتســاوي في الكلمــات مـع اخستلاف الاعتبار هو الذي أضفى على الكائنات طابع التساند والانتظام. "كل منها يسند الآخر

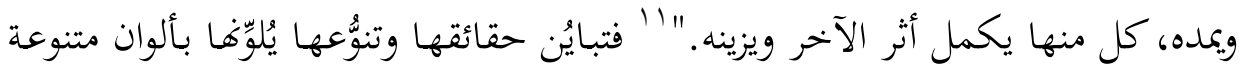
في طبائعها، بيد أن قدرة الله ومشيئته وحاكميته المتفردة تخلع عليها التساند والانسجام والتعبد والخضوع الاضطراري؛ استجلاءً لحقيقة قانون التوحيد فيها، وهو نسقها التعبدي، ومحورها الذي تدور عليه. فالتوحيد مقصد غائي بالنسبة إلى تباينها وتساندها وتعاوها، وهذه بالنسبة إليه عناصر ومظاهر تحمل جوهره وروحهه. بهذا المعنى فإنها صارت مرايا تعكس بتحليات هذه الأسماء، وتحكي نوعاً مـ جمالها،

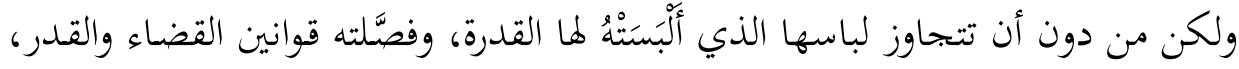

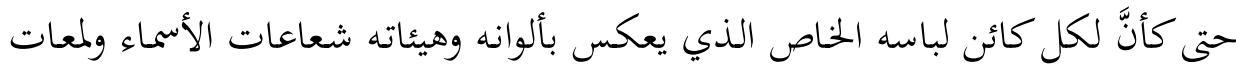

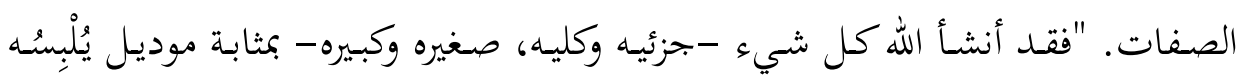

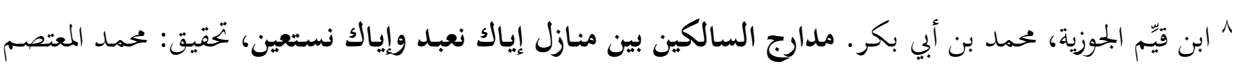

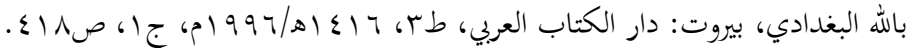

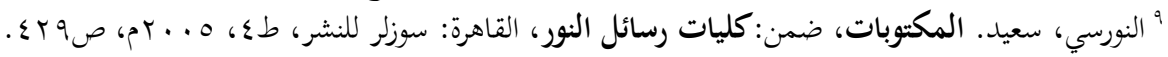

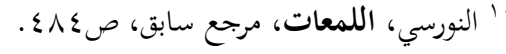

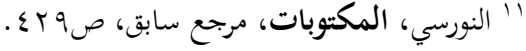




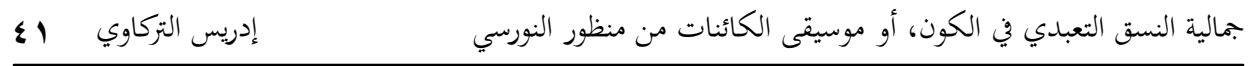

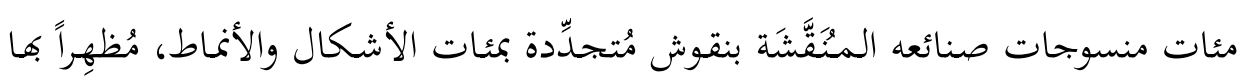

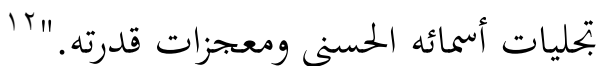

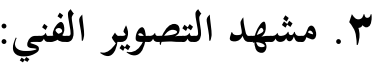

إذا ثبـت أنَّ ماهية الكائنـات وتمثُّالاتها هي بتحليات الأسماء، وثبت ضرورة أنْ يترتب

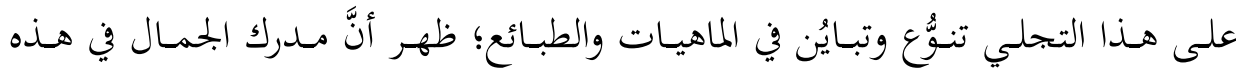
الكائنات راجع إلى طبيعة هـا التنوُّع والتبايُن. فعناصر الصورة الفنية المُتمثِّلة في الحركة والصوت والصورة والإيقاع " -عند النورسي - هي مادة المشاهد في شاشة الكون، وهي أعراض متنوعة، وكيفيات متباينة تعرض للمخلوقات، وتُشكِل مشاهد من التصوير الفني يشبه أنْ يكون مثل مشاهد السينما المتحركة، أو مقاطع المعزوفات والأنغام المتآلفة. غير ونير

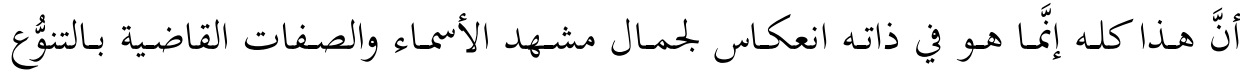
والتلوُّن.

وعلى هـذا، فبإنَّ الأمر دائر بـين مشهـد الأسمـاء والصففات ومشهـد التصـوير الفني

الجمالي. فالأول وجودي علمي، والثاني ذوقي إحساسي. وكل ما في الكون لا يخرج عن طبيعة هذين المشهدين. يقول النورسي مُستشعِراً تأثير الأسماء والصفات ودفعها الكون

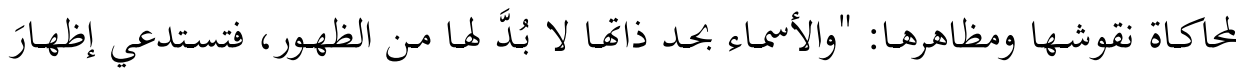

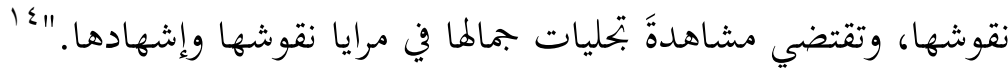

فهي أشبه مـا تكون بالمحرك، والكون كله بجال حركتها ومظهرهـا. يقول في ذلك:

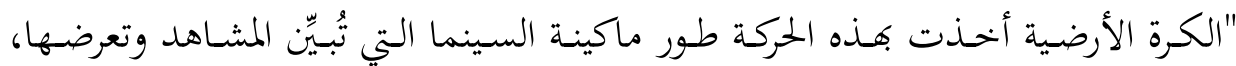

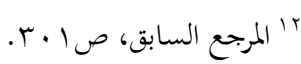

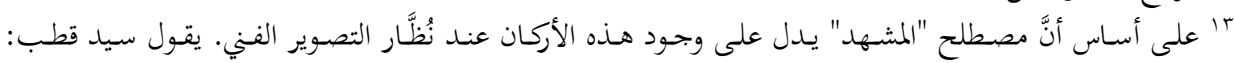

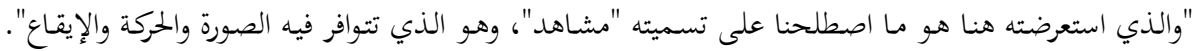


فحرَّكَت ما في السماوات من بخوم، وبدأت تسوقها سوق الجحيش، عارضةً مناظر جذابة

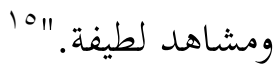

فالحركة في النص توحي بوجود إيقاع وصوت، ومنه تبدأ جذور الموسيقى في طبائع

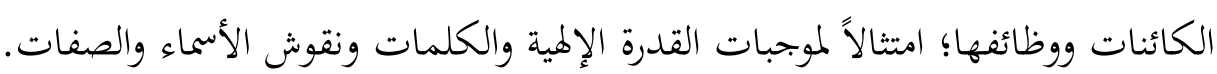

\section{ع ـ الجمال والجلال منبع التسبيح وأصل النسق التعبدي:}

الجـالال والجمــال صفتتان ترشـح بهمـا كليـات الوجـود وقوانينه الكونيـة، فلهمـا مـن

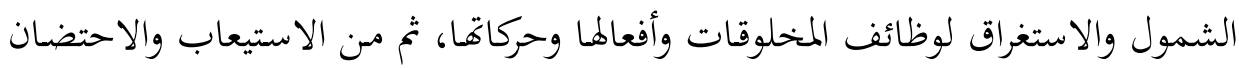

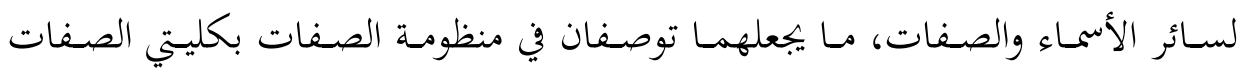
والأسماء. ولمذا بجد القرآن ينصبهما علمـين على نظامي (الربوبية) و والألوهية) في تدبير الكون والكائنات، على اعتبار أنَّ النظام الأول دال على الحاكمية والكبرياء، وقوام الثاني على الرحمة والرعاية. يقول النورسي في تفسير صدر سورة الفاتحة: "إنَّ لفظ (رب العبار العالمين) كما يتجلى منه الجلالال بسلسلته، كذلك يتراءى الجمال بسلسلته من (الرحمن الرحيم).

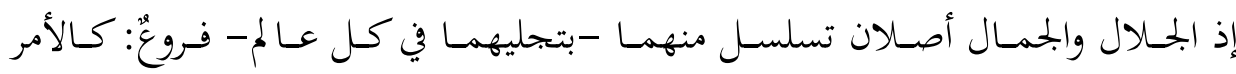
والنهي، والثواب والعذاب، والترغيب والترهيب، والتسبيح والتحميد، والخوف والرجاء إلى آخره....

فكل عناصر التكليف الشرعي لإٕنسان راجعة إليهما مثلما رأيت، وحيـث كانت "الكائنات قد ارتبطت بنظام علوي دقيق، واستمسكت بروابط عجيبة." لإ' وتلك حقيقة وحئة

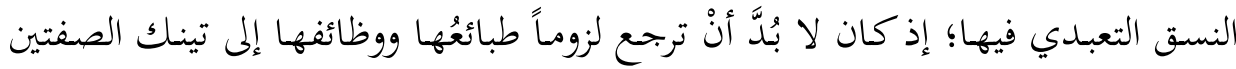

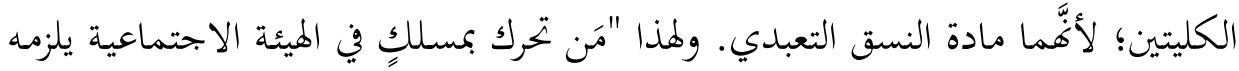

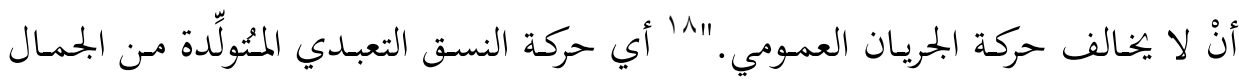

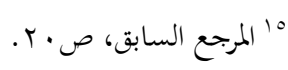

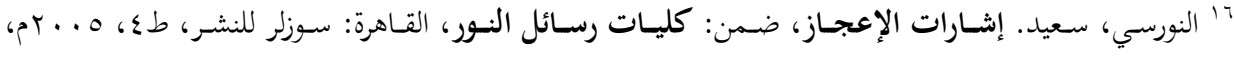




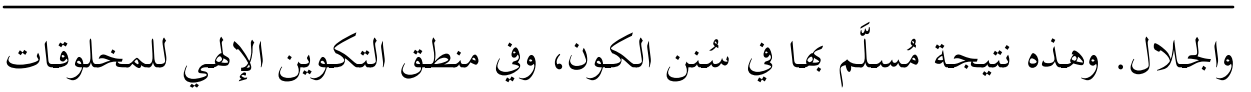
عامةً. وعلى كل حال، فإذا ثبـت أنَّ الجمال والجحلال هما مـادة النسق التوحيدي التعبدي

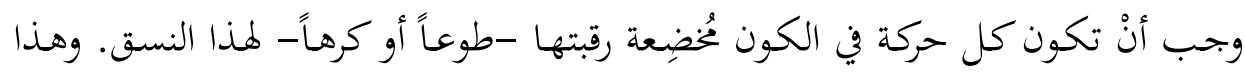

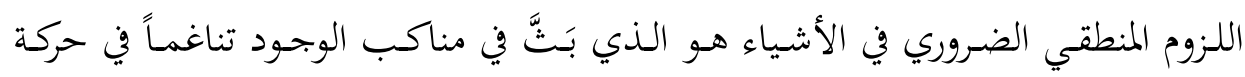

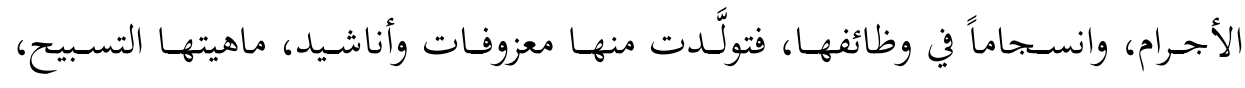

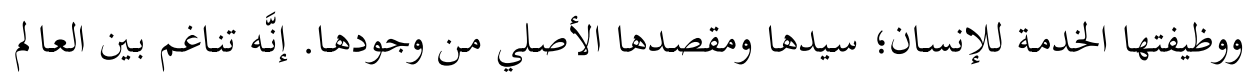
الأكبر (الكون) والعالم الأصغر (الإنسان). يقول بديع الزمان في ذلك: "إنَّ القدرة الإلهية

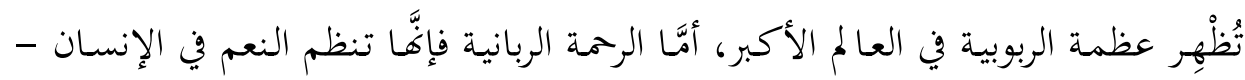

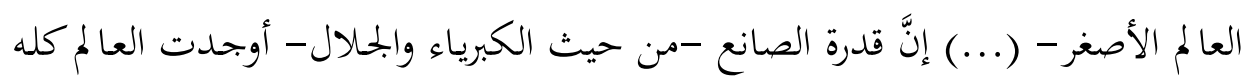

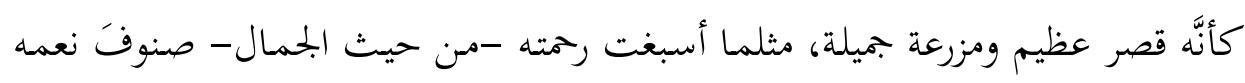

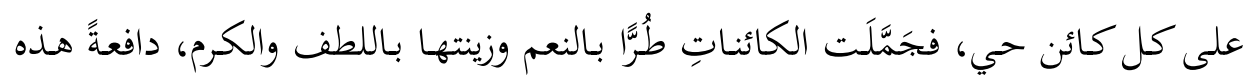

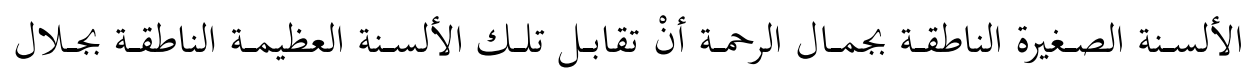

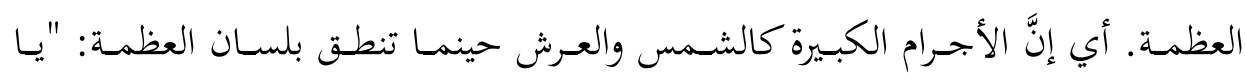
جليل، يا كبير، يا عظيم"؛ تقابلها ألسنة الرحمة في البعوض والسمك والكرة والحيوانات الصغيرة:

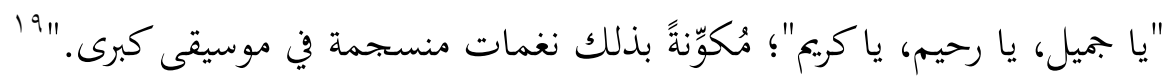
وإذا تباينــت بحليـات هـاتين الصـفتين في الوجـود فلـيس ذلـك بضــارٍ لنسـقهما وحاكميتهما. وقد لفت النورسي انتباه المتأمّل إلى ذلك بقوله: "أنصت إلى السماء كيف إنى

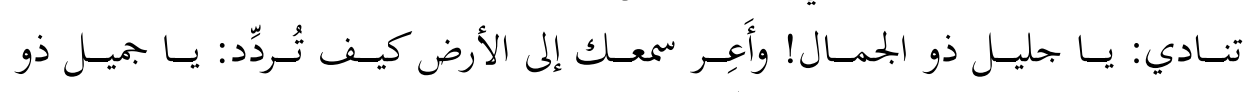

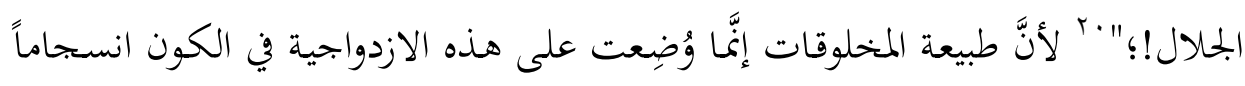

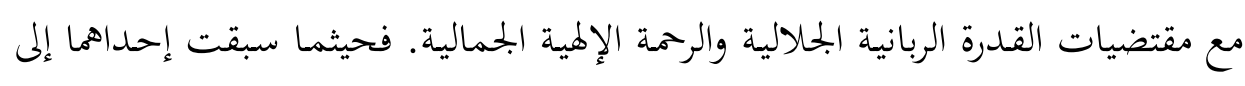

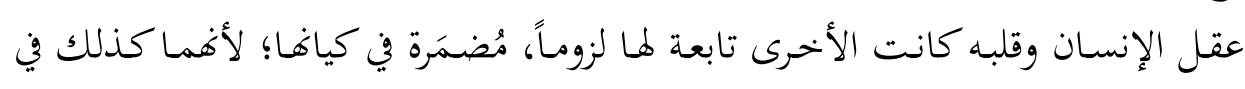

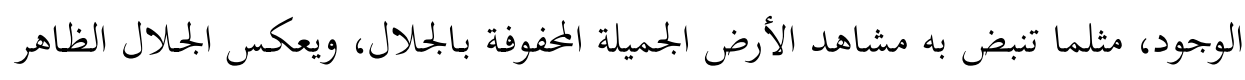

$$
\begin{aligned}
& \text { 9' النورسي، المكتوبات، مرجع سابق، صع . r. }
\end{aligned}
$$

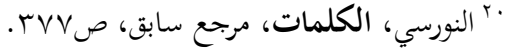


في مخلوقـات السـماء الرهيبـة مظـاهر الجمـــال. والمقصـود أنَّ الجــلال والجمــال همـا مــادة

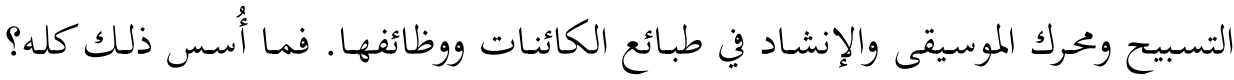

وما بحلياته؟

\section{ثانياً: موسيقى الكائنات: الحفريات الفلسفية وتركيب المفهوم}

\section{ا ـ الجذور المعرفية الفلسفية:}

يرجع نسج الألحان وأداؤها في صناعة الموسيقى إلى مقولة الفعل والانفعال، 'ب وهي

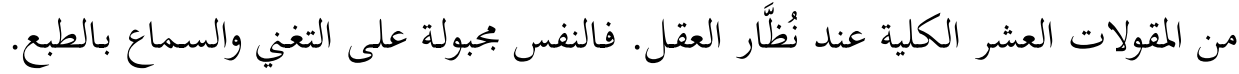
وفي جوف الروح موضع لانفعال الكائن بالصوت والترنم. وقد حلَّد نُظَّار الموسيقى أنواع

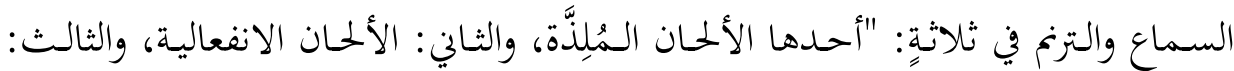

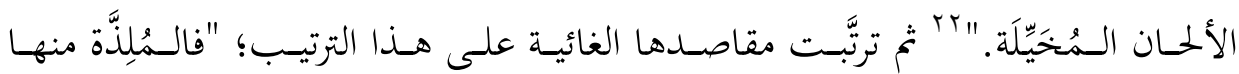
تستعمل للراحات ولكمالها، والانفعالية تستعمل حيث يقصد بها حدوث الأفعال الكائنة

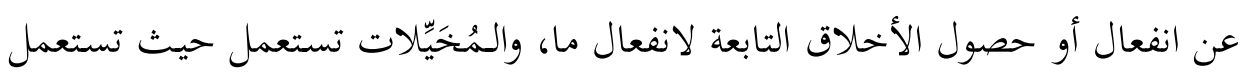

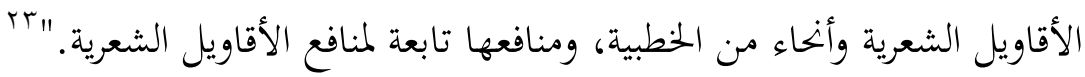
والـمُلاحَظ علـى هـذا الـنص التصـنيفي للفـارابي أنَّ اللـذات وغايـات الـنفس مـن

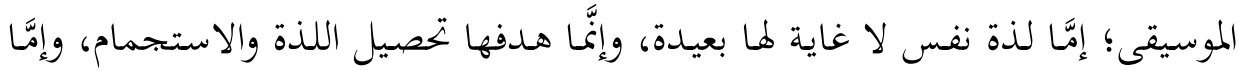

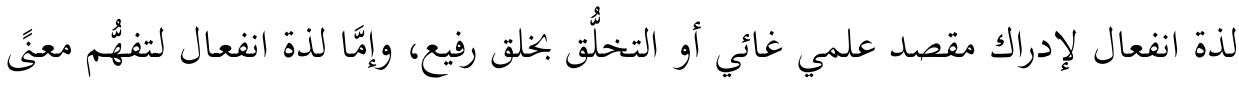
لفظي نظمي أو نثري.

وأكمـل هـذه المقاصد القسم الثـاني منهـا؛ لارتباطه بـالروح، والتزازه بغايـات شريفة

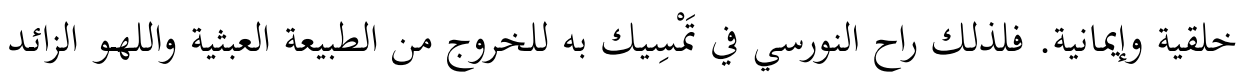

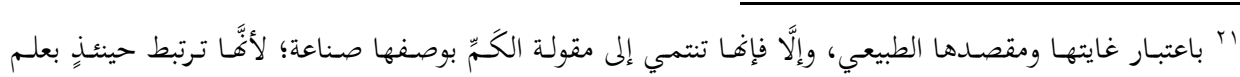
الرياضيات والحساب. ونظرة النورسي إليها بحسب الاعتيات الاعتبار الأول، لا بالاعتبار الثاني.

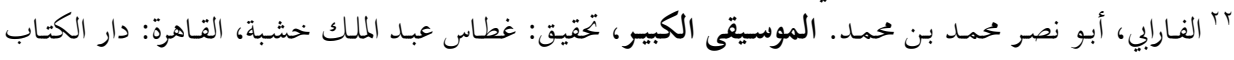

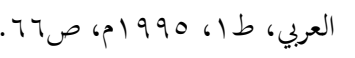

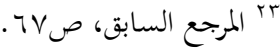


للموسـيقى والإنشـاد، وتلميحـاً منـه إلى الصـبغة الطبيعيـة الفطريـة للأصـوات والحركـات والإيقاعات الكونية حيث تتناغم مع الشعور، وتتساوق مع المواجيد.

وعلى هذا، فإِنَّ حركة الكائنـات إنَّا هي تصويتات وترانيم ساذجة فطرية عَرَضَت

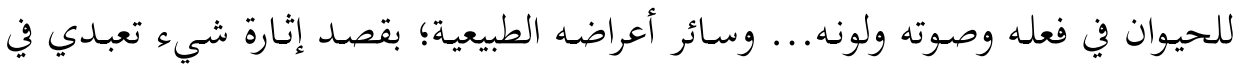

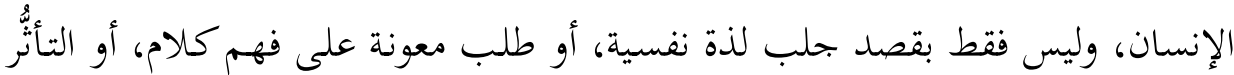
بمضمونه.

إنَّ استعداد القلب لقـراءة حركـة الكائنـات الفعليـة والصـوتية جعـل النورسي موهبـة

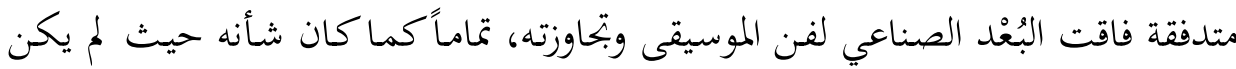
دارياً بقواعد القريض وصناعة الشعر مـن حيث هي صناعة، لكننَّ تأوهاته المتدفقـة مـن مشكاة اللطافة الذوقية في جوف الفطرة الساذجة الأمية للغلام منذ نعومة أظفاره؛ جعلته

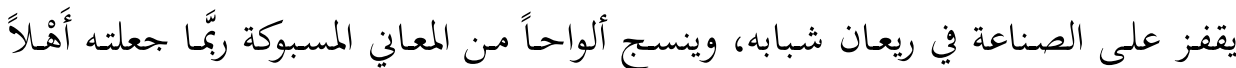

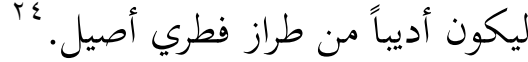

وهذه الأغراض والمقاصد الثلاثة هي التي دفعت الإنسان إلى إنشاء صناعة الموسيقى

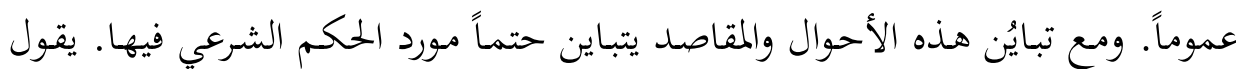

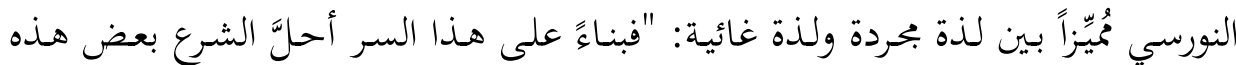

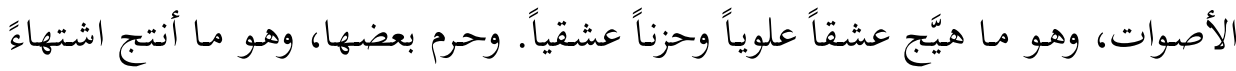

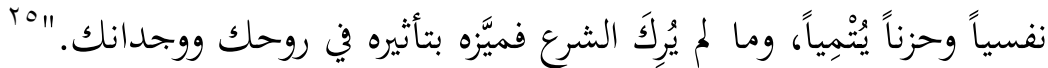
والدافع في الأصوات هو رقة الطبع وتفاعله مع حركة الكون، كأفَّا فارت من بوح

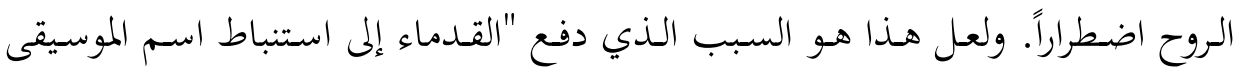

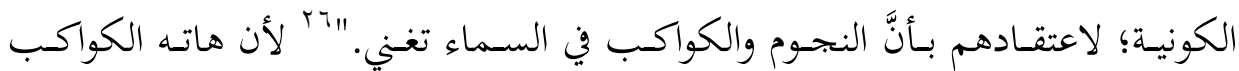
والنجوم منجذبة بالشوق والإرادة، مطبوعة على الانفعال.

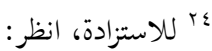

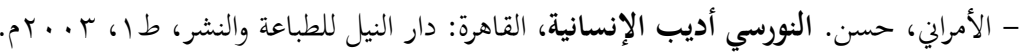

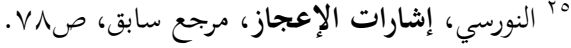

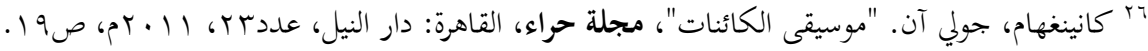


ومتى سمَّيناها (موسيقى) كان كتسمية الزهد (تصوفاً) عند نُظَّار التصوف، وكتسمية

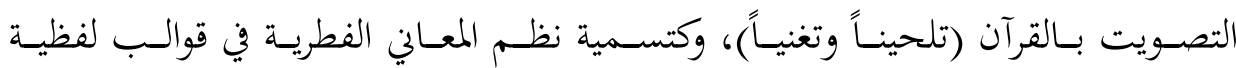

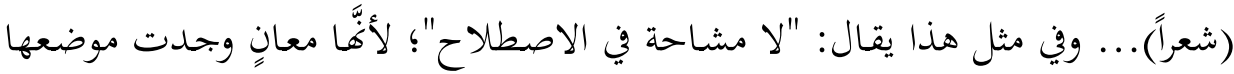

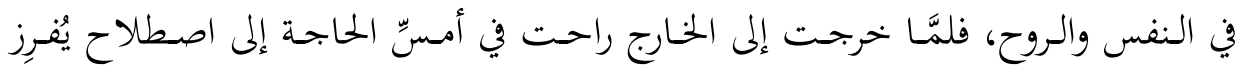

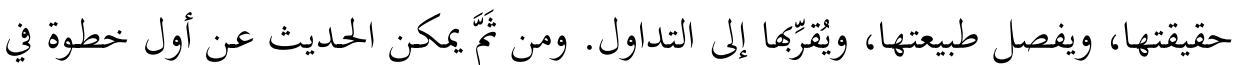

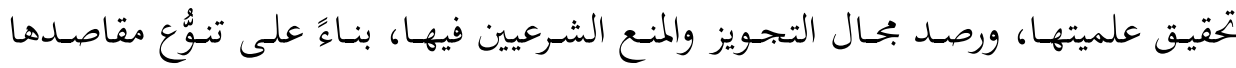
وغاياتما.

ولقد كان للبُعْد الديني وذريعة تحصين قواعد الشريعة دورهما في منع التسمية قديماً.

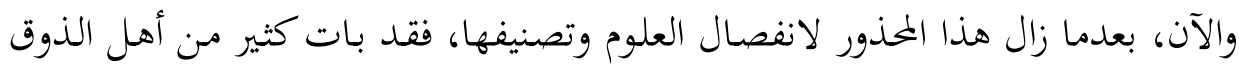

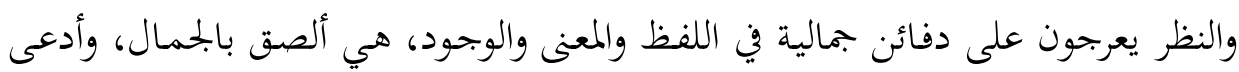
لنفث حقائق موسيقية في النفس، مثل: سيد قطب، ومصطفى صادق الرافعي، وعباس محمود العقاد، وعبد الله الطيب.

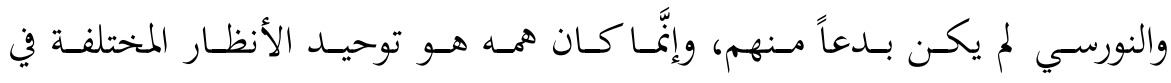

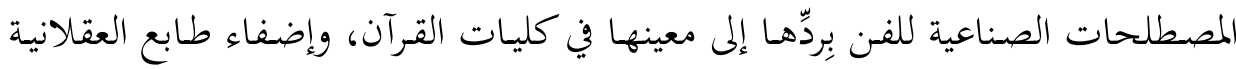
المشتركة عليها، والتوفيق بين الصناعي المكتسبب (الموسيقى، والترنم) والفطري في الطبع

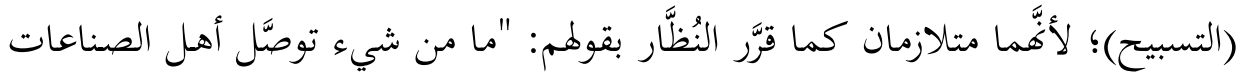

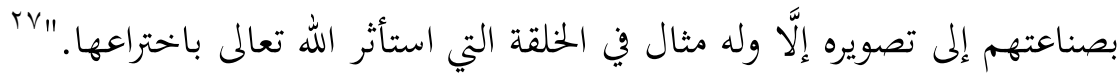
فمـادة الموسيقى وموضـوعها (النغم) طبيعيـان، وصـورتا الصـناعية التي تُعنى برصـد

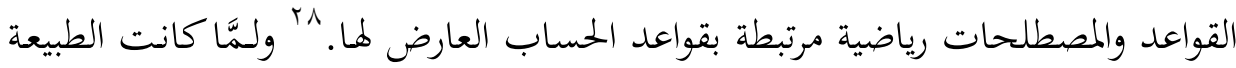

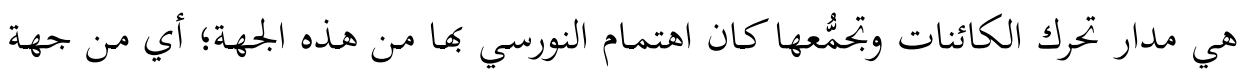

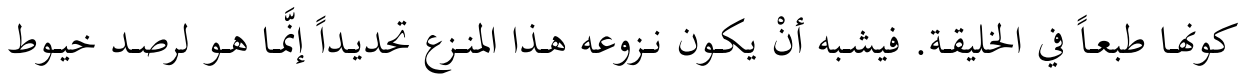

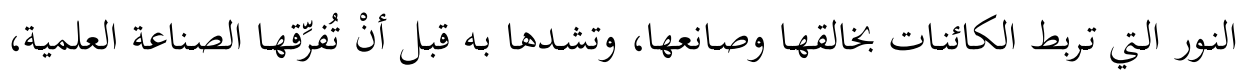

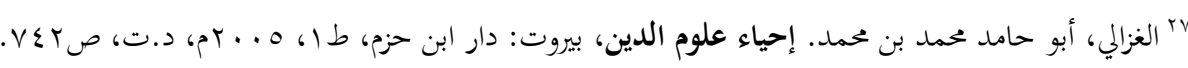

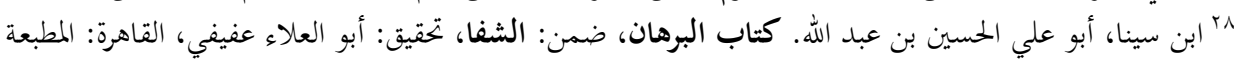

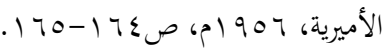




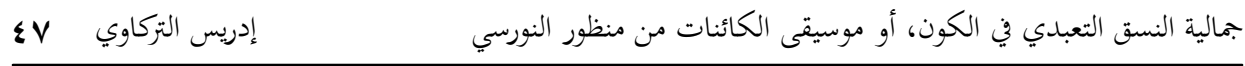

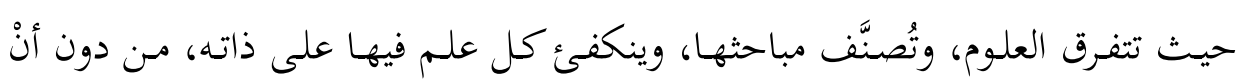

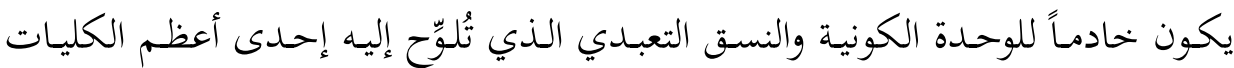

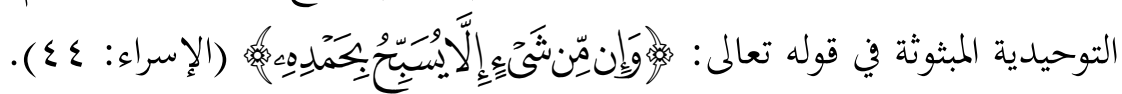
ولهـذا تـراه في رسـائله كلهـا يُسمَسِكُُ بهـذه الكليـة القرآنيـة المسـتوعبة لنفـث أذواقهه،

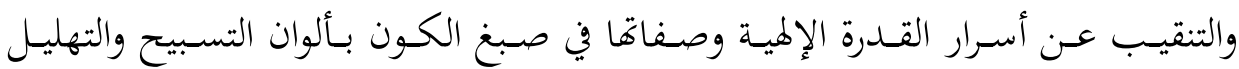

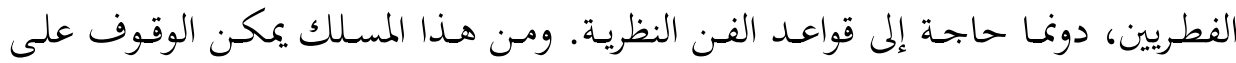

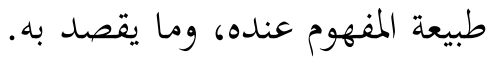

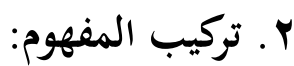

مرتع نظرية موسيقى الكائنات ومادتا عند بديع الزمان هي منظومة الجمال بمشهديه

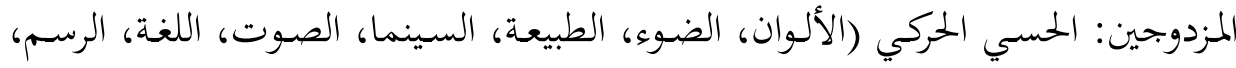

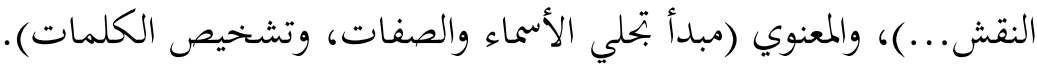

فمفهومها معقـد ينطوي على أسـرار ومقاصـد ودلالات، هي دوائر علميـة وجماليـة

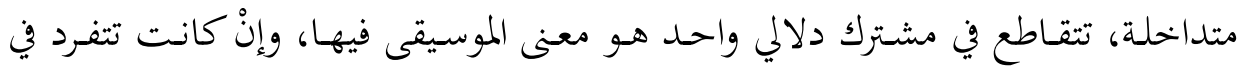

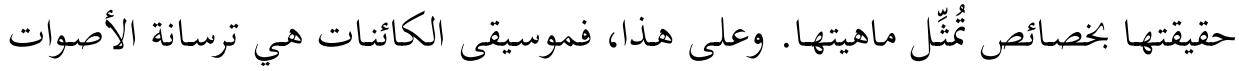

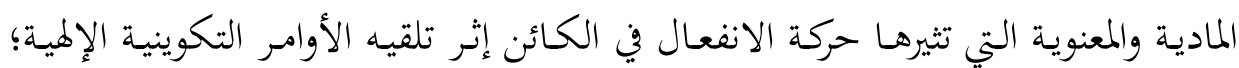
قصْد إظهار وظائف النسق التعبدي المنوطة به.

وعنــ تفكيـك هـذا التعريـف الكلـي الـذي نظمنــاه مـن منطـوق النصـوص النوريـة ومفهومها، بنده يحتضن عناصر ثلاثة متداخلة في تركيب المفهوم، بوصفه نظاماً معقداً يتداخل فيه الطبيعي مع الحسي، والشرعي مع الكوني. وهذه العناصر هي: أ. حركة انفعال الكائن نتيجة تلقي الأمر التكويني (أو بتحيد الكلمات المكتوبة).

$$
\text { ب. بحموع الأصوات المادية والمعنوية. }
$$

ت. مقاصد تلك الأصوات ووظائفها (أو استجلاء مظاهر النسق التعبدي). فالعنصران الأوليان يُجلِّيان طبيعة خلق الكائن، وماهيته، وما يعرض لها. والعنصر

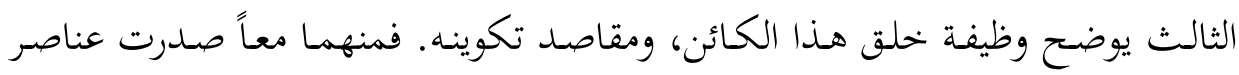


الجمال الموسيقي. ويمكن استجاءلاء مظاهر العنصـين عن طريق التكشيف عن المعاني والأسرار لهذه الكليات الثلاث المُمثّلة لحقيقة النظرية، وذلك كله فئه فيما يأتي.

ثالثاً: التجليات الموسيقية في ماهية الكائنات ووظائفها

ا ـ ـ طبيعة الكائنات وماهيتها:

\section{أ. حركة انفعال الكائن نتيجة تلقي الأمر التكويني:}

يوجد في جوف الكائن وباطنه الشعوري نويً معنوية هي آلات رصد الأمر الإلهي

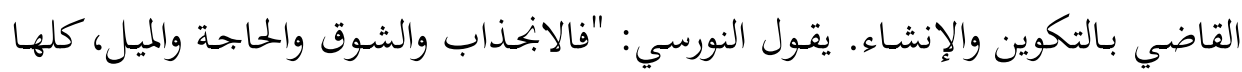

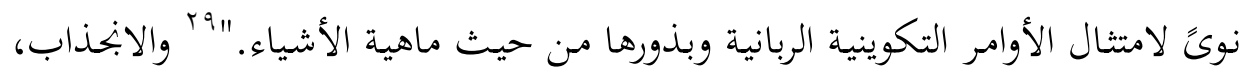

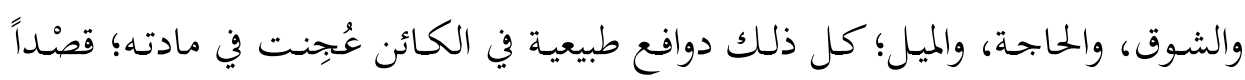

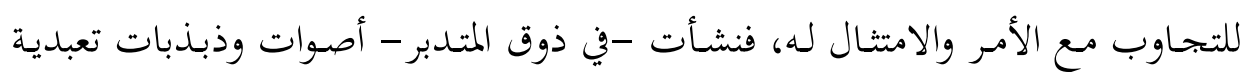

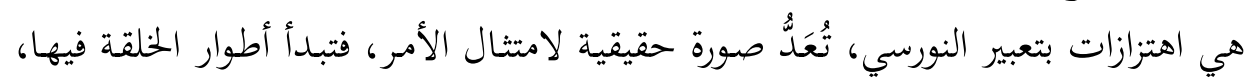

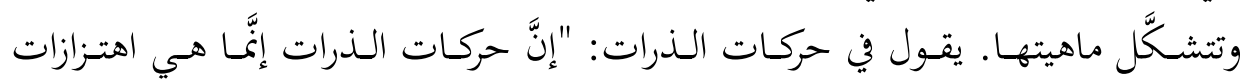

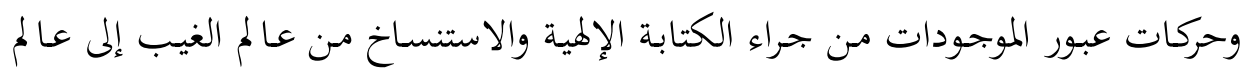

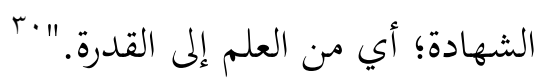

وهذه الاهتزازات هي منشأ التصويت في الأجسام عموماً. 'ب غير أنَّ النورسي يُصِّرّ

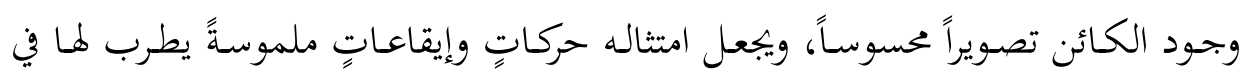

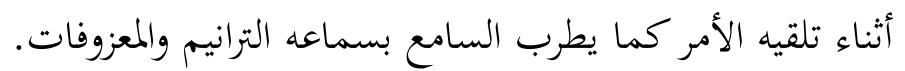
والنورسي مـا لبـث يستمد مـن قواه الوجدانية وانبعاثه الإيماني قوانين أخرى، تسوق

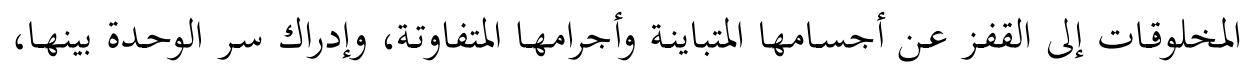

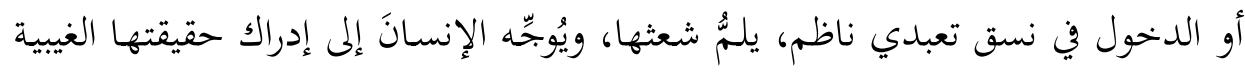

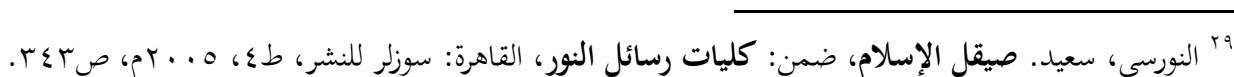

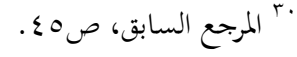

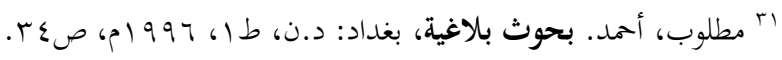




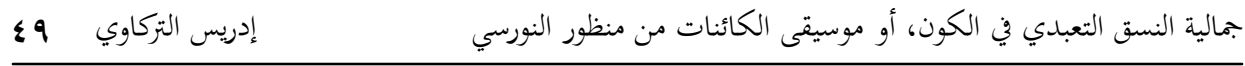

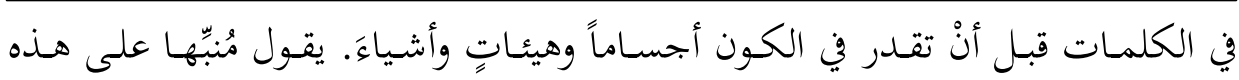

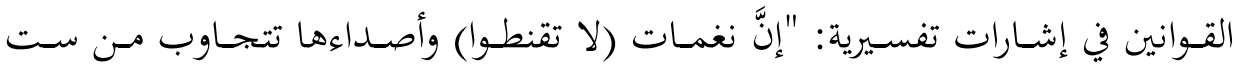

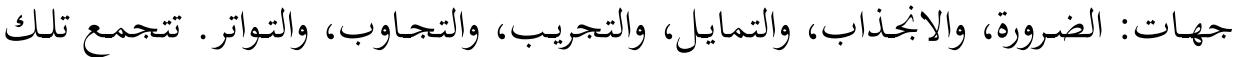

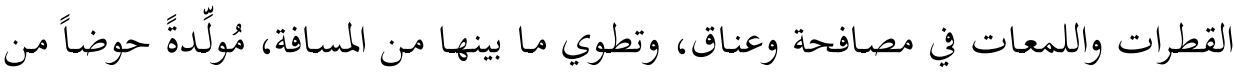

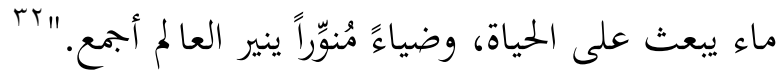

والحـوض والضياء يخفيـان تحتهمـا تجليـات التوحيـد، أو الأحديـة بحسب تعبيره في رسائله. أمَّا لفظا العناق والمصافحة فيرمزان إلى مقصد الأخوة والوحدة، ونبذ الاختلاف

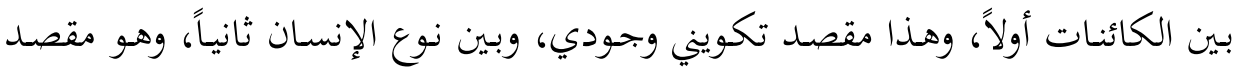

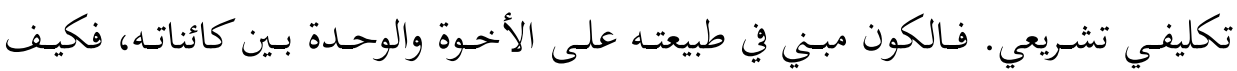

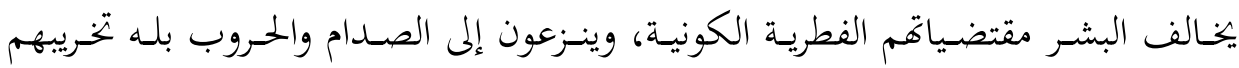
منظومة تلك النعم والكائنات بتشييئها واستغلالها بكل خساسة ولؤم؟ الكرائه إنَّ قلم القدرة الذي كتب الكلمات ودفع المشيئة لتشخيصها في الأرض يوجب أنْ

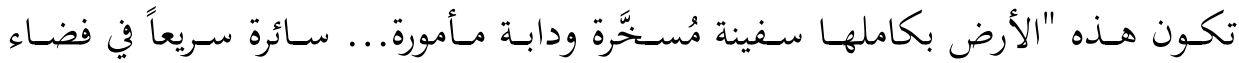

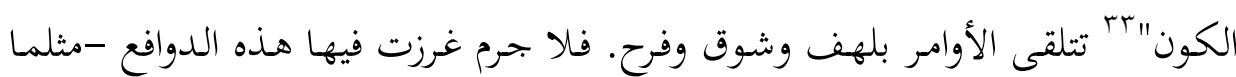

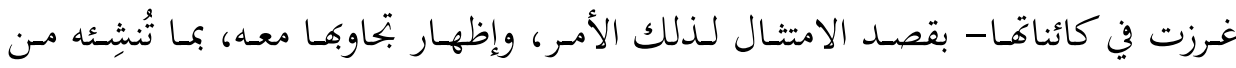

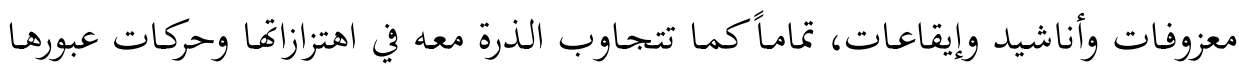
من الكمون إلى التجلي مثلما سبق.

\section{ب. مجموع الأصوات المادية والمعنوية:}

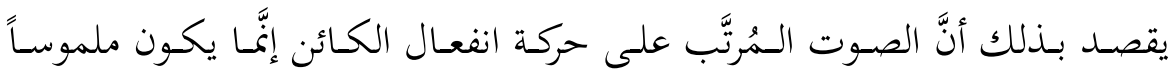

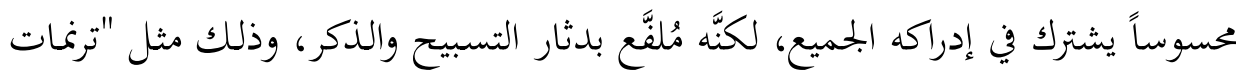

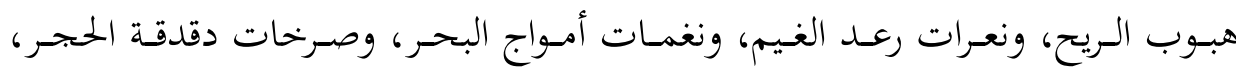

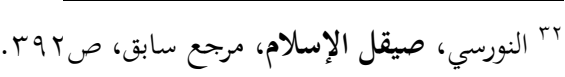

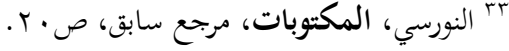




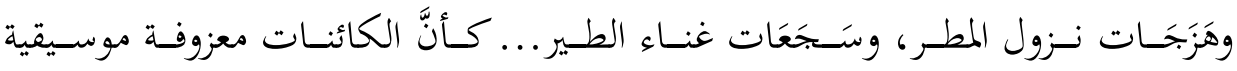

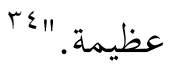

فكل حركسة ذاتيـة أو عرضسية في الكـون إنَّما هي تسبيح وتمجيــ لبارئهـا، واعـتراف

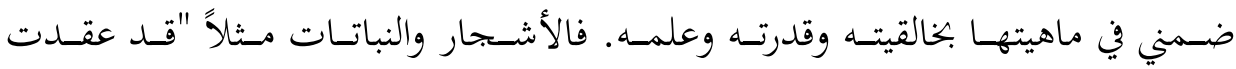

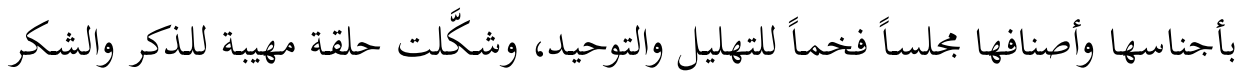
من خلال ثلاث حقائق كبرى كلية.... بالألسنة الفصيحة لأوراقها الموزونة.

$$
\text { وبالكام الجزيل لأزهارها الجميلة. }
$$

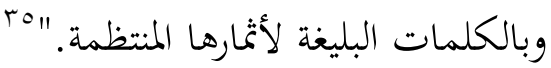

وهذه الدلالة المزدوجة للصوت في الكائنات، أقصد أصواتحا المادية المدركة والمعنوية الرمزية الشعورية، لا تفترق منعزلةً عن بعضها بعضاً في منطق النورسي الإحساسي، وإنَّا

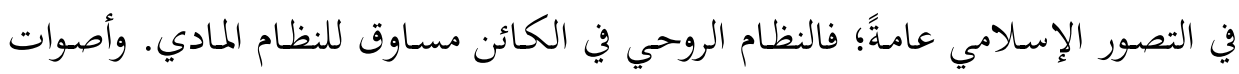
الطبيعي وإيقاعاته في الخارج هي انعكاس لـذات التسبيح والتمجيد في باطنه. فالماهيـة

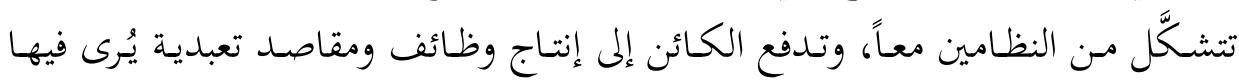
اللونان معاً في لوحة نسقية متكاملة مندبحة، لا يجبوز تفكيك محتوى اللونين فيها، وأيُّ إني

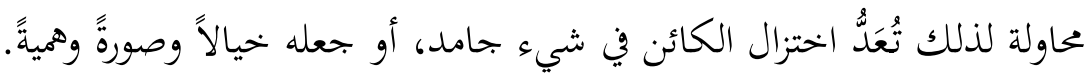
وكذلك كان الصراع الرمزي في الماضي بين الاشتراكية المادية والروحية المسيحية، في

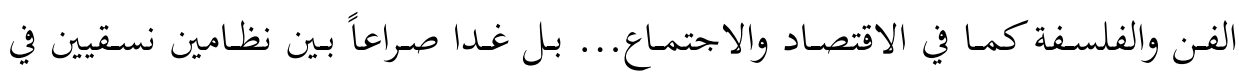
أغلب التصورات الفلسفية: المادة في مقابل الروح. والإسـلام في هـذا الخصـوص يُوجِّهـ المنطسق الإنسـاني إلى إدراك أنَّ الحقــائق الشـرعية

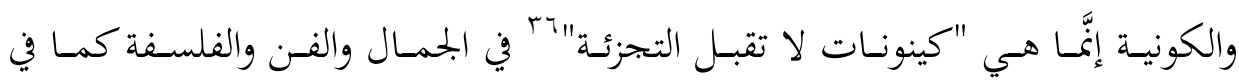

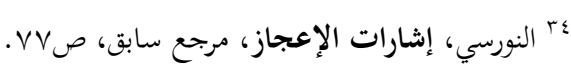

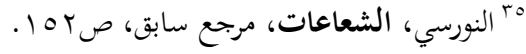




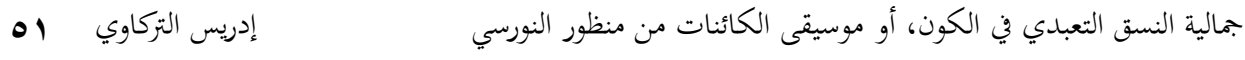

التعبدات والمعاملات والأخلاق. فالكل منضود في عقد النسق التعبدي. وهو الذي ربط

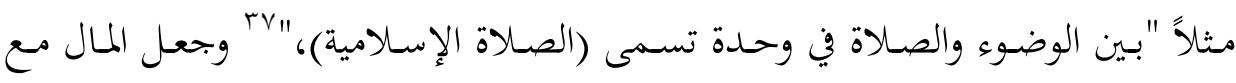
المواساة هو نفس الزكاة في الإسلام.... وهكذا في كل شيء؛ أجسام الكائنات ومنظومة

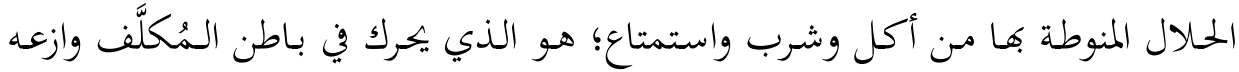
المسمى الإيمان، فيُكوّن حقيقة الإيمان الكبرى.

وكليات القرآن ما لبثت تُنبِّه لهذا التساوق بين النظامين في صورة نسقية تعبدية؛

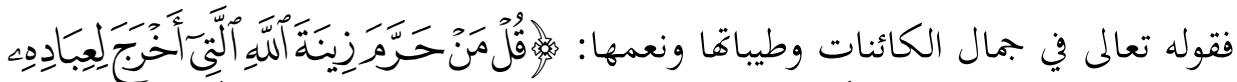

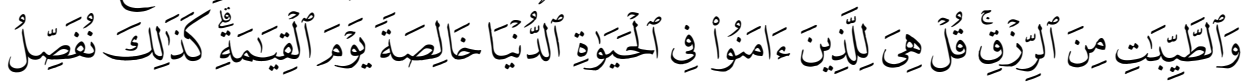

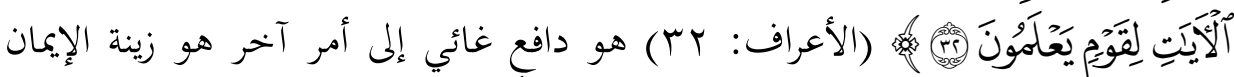

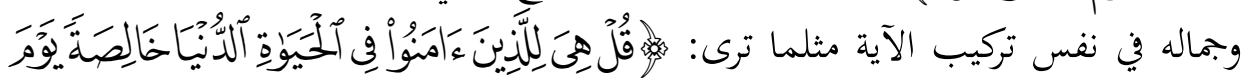

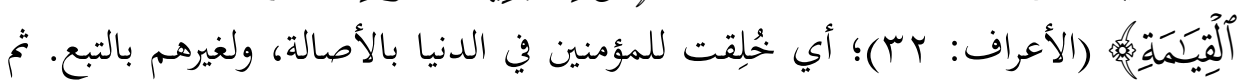

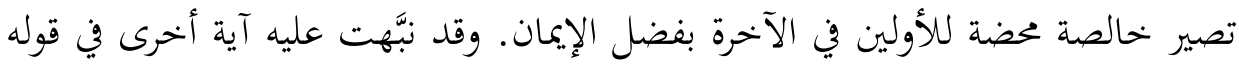

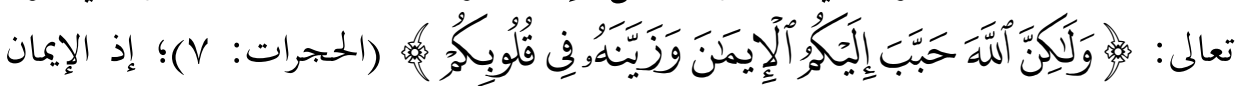

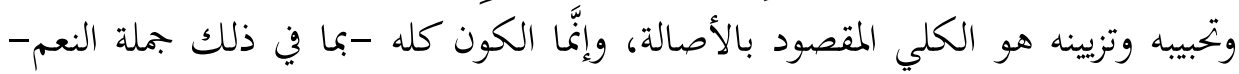
مسوق لخدمة هذا المقصد الجليل، فنصبت للتناول قصْداً ابتلائياً كونياً مشتركاً، فصار فئه

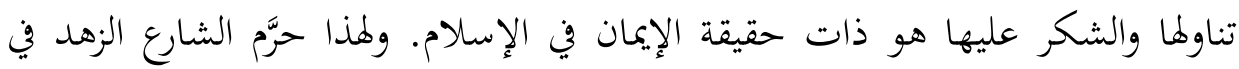

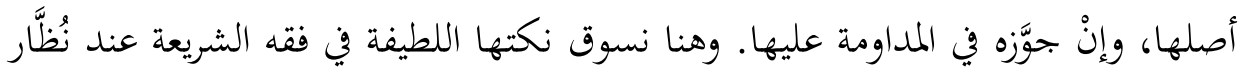

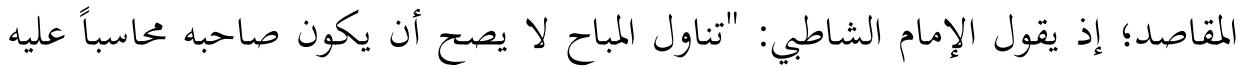

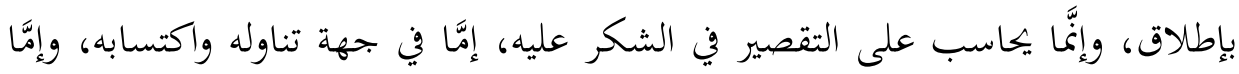

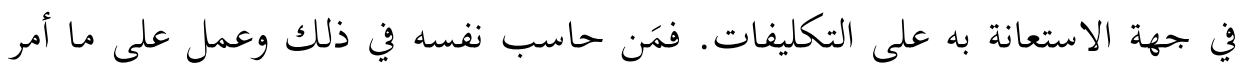

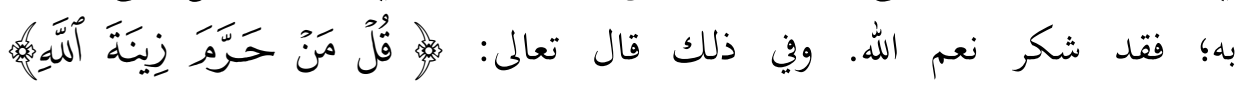

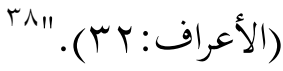

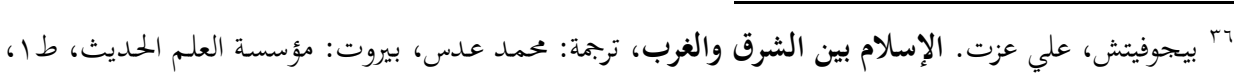
.

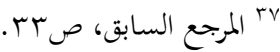
^^ الشاطبي، أبو إسحاق إبراهيم بن موسى. الموافقات في أصول الشريعة، تحقيق: الشيخ عبد الله دراز، بيروت:

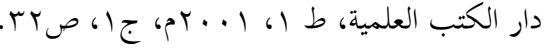




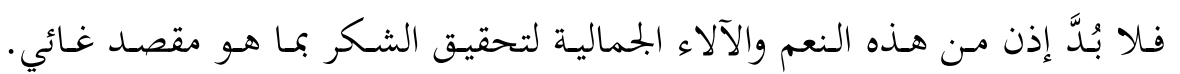

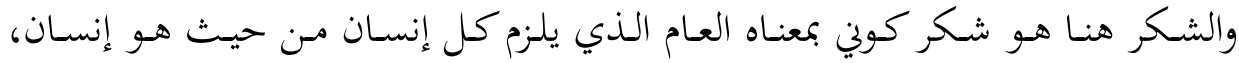

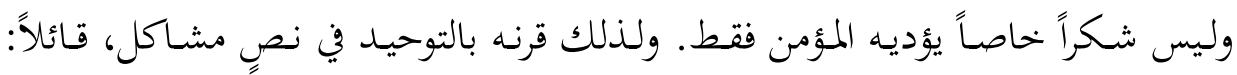

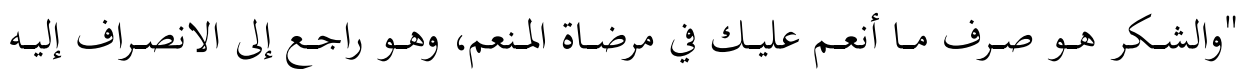

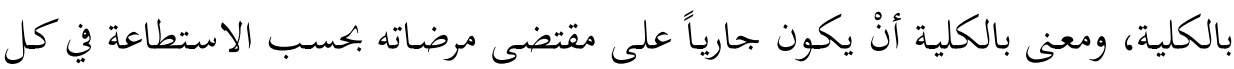

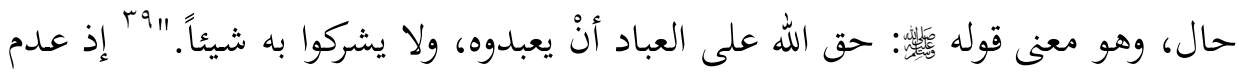

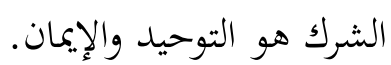

والمقصود من الآية -المسوقة عند الشاطبي- أنَّ تناول النعم بوصفها أشياء مادية

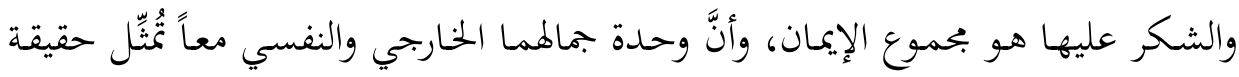

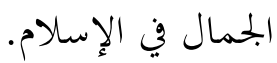

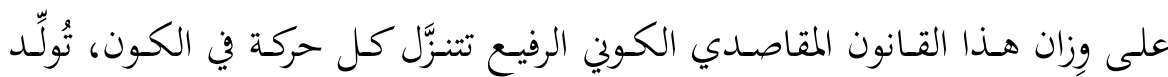

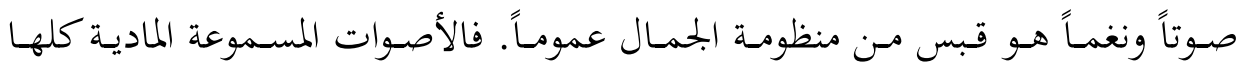

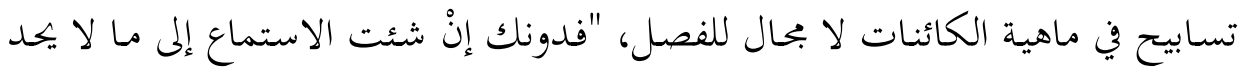

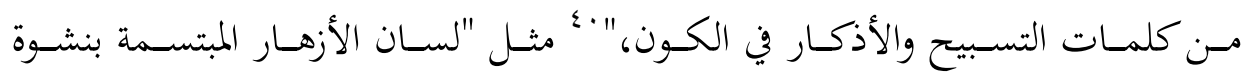

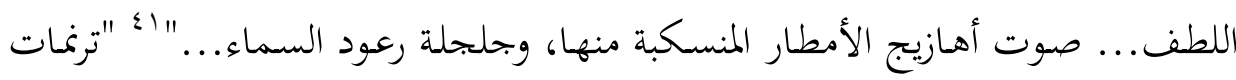

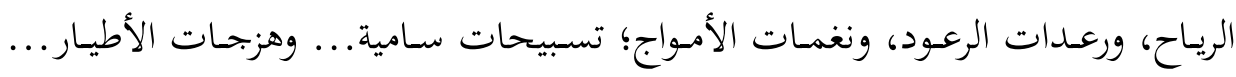

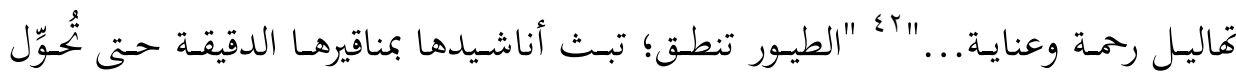

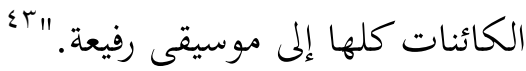

غير أنَّهَ يوجد جسم وروح، ولكالِّ حقيقته منفرداً، ويبقى للإسلام لمسته الإعجازية في التوفيق بينهما. وهذا هو السر العجيب فيه دون سائر الملل والنحل.

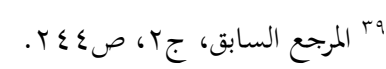

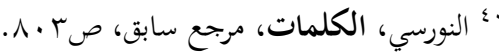

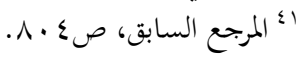

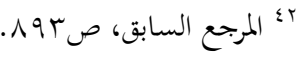

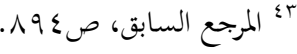




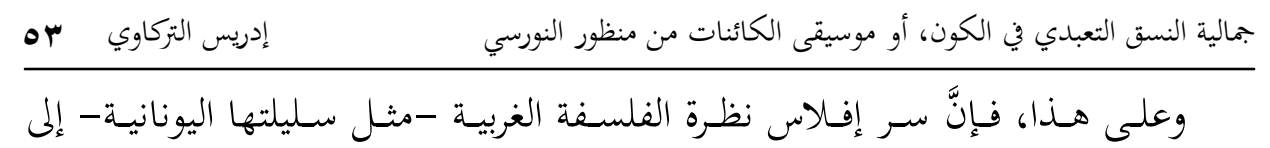
الكون، هو تشييء الكائنات، وتفضيل أقواها وأضخمها في إشباع الغريزة على أصغرها

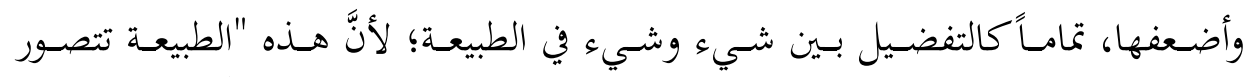

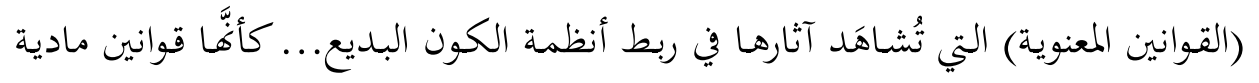

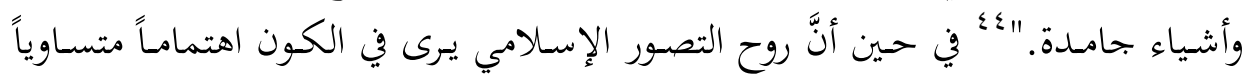

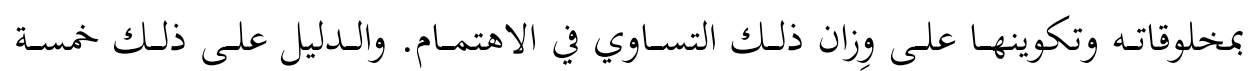

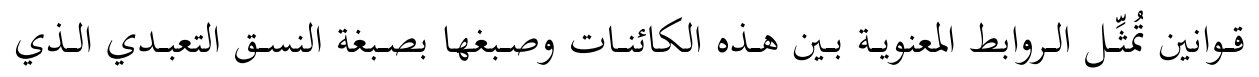

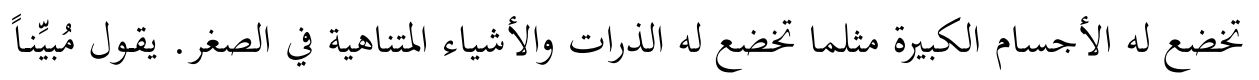
هذه القوانين: "لا مراتب في تلك القدرة، فتتساوى بالنسبة إليها الذرات والنجوم والقليل

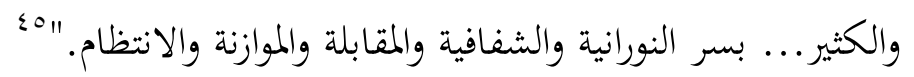

إنَّ ماهية كل كائن -عند النورسي - إنَّا تحمل بالقوة هذه القوانين، وحيث وُجِحدت

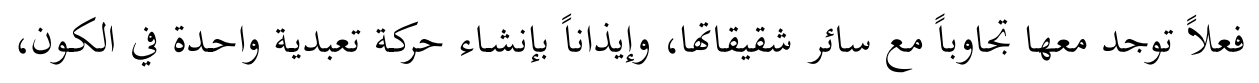

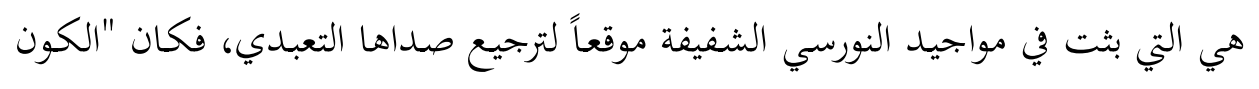

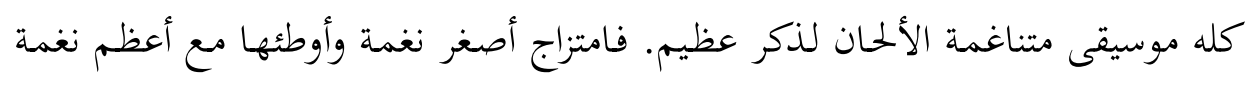

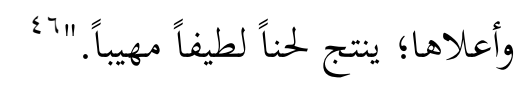

فـلا عجـب أنْ يشـار إلى الـذرّة، وإنْ كانـت مخلوقاً متناهيـاً في الصغر، غـير أنَّ لهـا شـرف تحريـك المخلوقـات بـأمر إلهي، فتغـدو كطرف إبرة مركزيـة في نسـج الأسطوانات

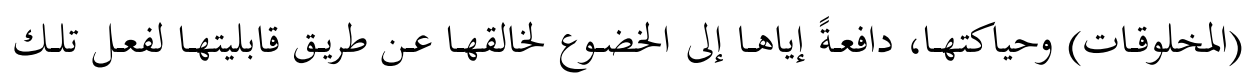

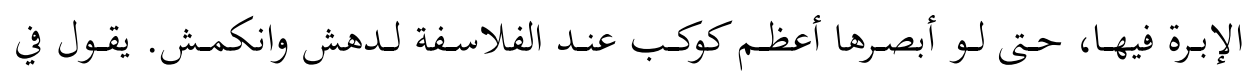

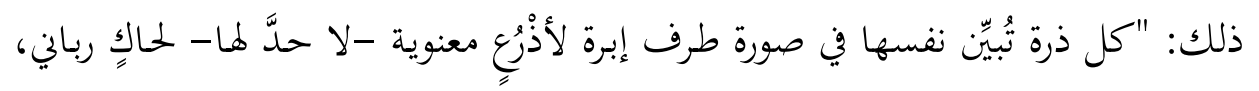

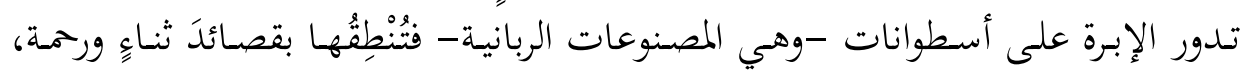

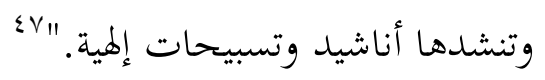

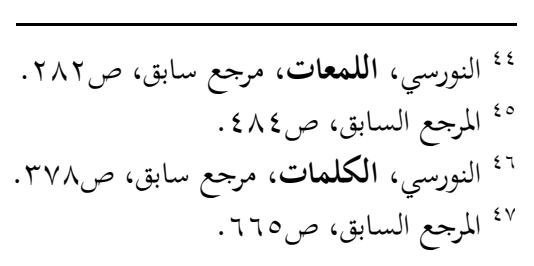


فالتسبيح والإنشـاد قانونان رمزيان في وجـدان النورسي يهفو إليهما دائماً؛ لتصوير

حقيقة الامتثال التعبدي في الكائنات، ورصد مشاهد التصوير الفني القائم على الصوت والحركة والإيقاع وغير ذلك.

إنَّ تصوير ماهية الذرّة على أَََّّا طرف إبرة تمخر عُبـاب المنسوجات والمصنوعات، وما يستلزم ذلك من قابلية وانسجام وامتنال مـن هذه المصنوعات؛ إنَّا يرسم في مخيلتنا

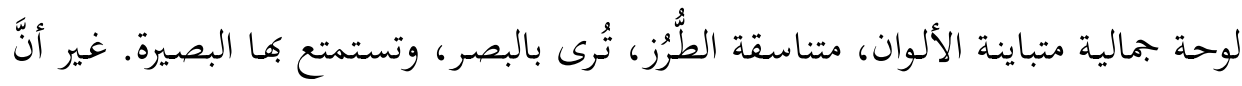

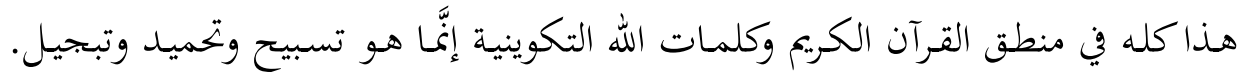

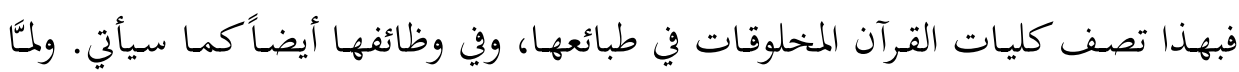
كان النورسي فنَّ قرآنياً لا يبارى فقد كان تشبثه بطبيعة المصطلحات والمسميات هنا بمان هي نسخة أصيلة من طبيعة هذه المفاهيم والمسميات نفسها في الكليات القرآنية. ومن هنا، كان لجوؤه إلى لفظ التسبيح ليسلس له لفظه المرادف في الصناعة، وهو الموسيقى والإنشاد، فيصيرا أشبه بالمتنـازعين على المعمول الواحـد؛ مـن الناس مَن يُرجِّح هذا لقربه من المعمول، ومنهم مَن يُرجّحح الآخر لسبقه في التركيب. وكذلك هنا؛ إذ لفظ (التسبيح) مفهوم قرآي يجمع الصوت الحسن مع التعبد، فهو أسبق إلى الفطرة، وأعظم

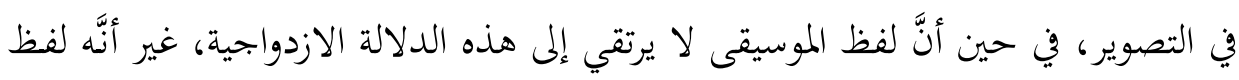
تقعيدي صناعي، فكان أدل على الصناعة من الأول الدال على الفطرة.

\section{Y I ـ وظائف الكائنات ومقاصدها الوجودية:}

يضـع النورسي الكـون في صسورة منصـة، ويرصد فيها الأحسداث والوقائع التي تُمتّلّها

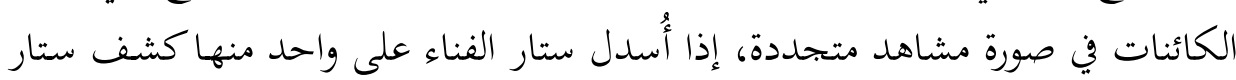

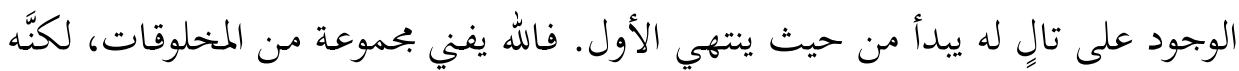

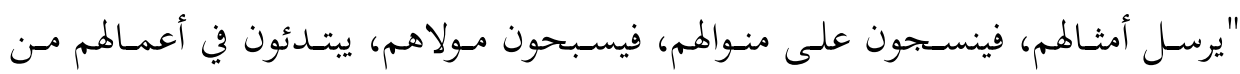

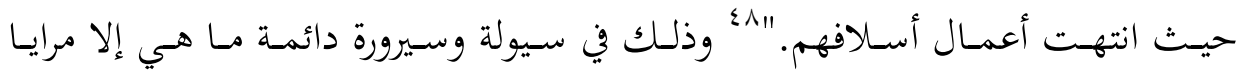

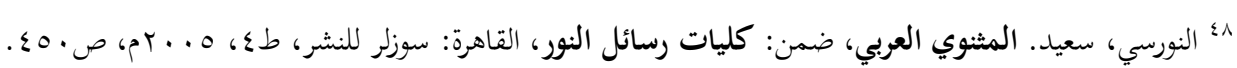




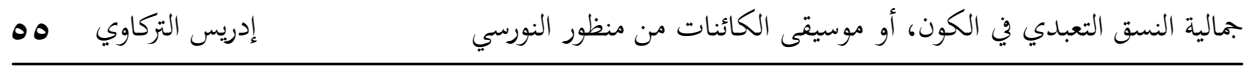
ومظاهر متبدلة للأسماء، والصفات، والأفعال الإلهية، وبتحلياتا الوجودية ج؛ . يقول كاشفاً

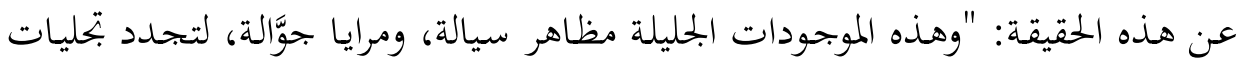
أنوار إيجاده سبحانه بتبدل التعيُّات الاعتبارية: أولاً: مع استحفاظ المعاني الجميلة والهويات المثالية. وثانياً: مع إنتاج الحقائق الغيبية والنسوج اللوحية. وثالثاً: مع نشر الثمرات الأخروية والمناظر السرمدية. ورابعاً: مع إعلان التسبيحات الربانية، وإظهار المقتضيات الأسمائية. وخامساً: لظهور الشؤونات السبحانية والمشاهد العلمية."•

هذه هي وظائف الكائنات ومقاصدها التكوينية في الوجود، لا يخرج عن إطارها أيُّ

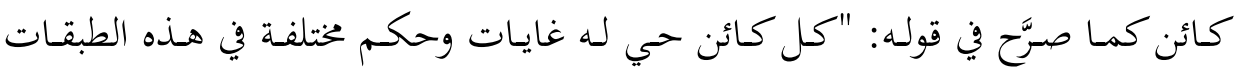
الخمس." اه فما حقيقة هذه الوظائف

\section{أ. أسرار الوظائف في مآلات الوجود والعدم:}

تُعِرٌُ هذه الوظائف والمقاصد الكلية الوجودية بأن حركة الكون كلها دائرة بين الوجود والعدم المضاعفين: وجود دنيوي وأخروي، وفناء دنيوي وأخروي. بناءً على ذلك، ونظراً

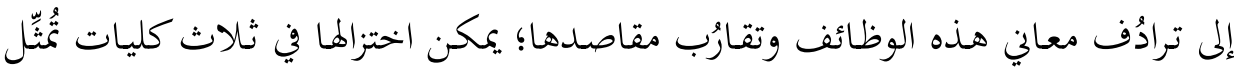
حقيقة فلسفة الوجود والعدم في التصور الإسلامي: الكلية الأولى: ترسيخ معاني الأشياء في قوة (الحافظة) البشرية بعد فنائها وكتابتها في

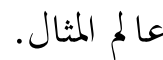
الكليـة الثانيـة: الدلالـة على وجـود عـالم المثـال وتمراتـهـ الأخرويـة، أو فلسـفة الجــاء

$$
\text { 1. }
$$




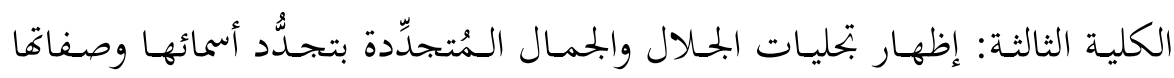

الحاملة لما.

تقتضـي الكليـة الأولى وجـود قـوى إدراكيـة في الإنسـان خلقهـا الله فيـه، وركَّبها في

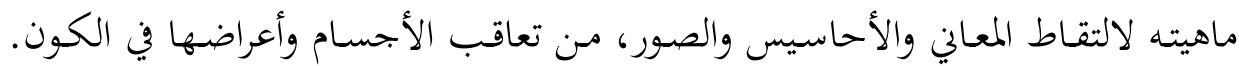
وهذه القوى الباطنية كما هي عند العلماء: القوة الباصرة التي تبصر الموجودات، والقوة الحيالية التي تبقي على صور تلك الموجودات بعد رؤيتها، فهي تدرك الصور، ثم القوة

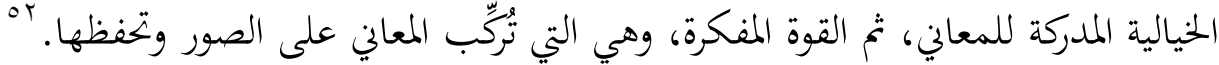

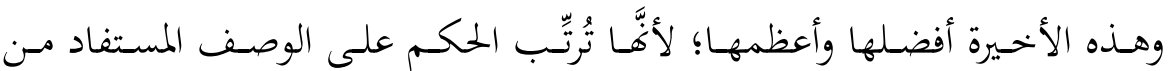

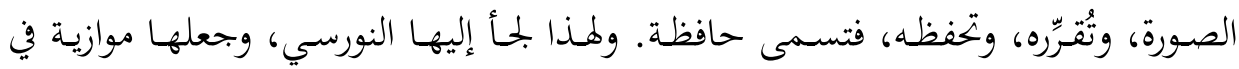

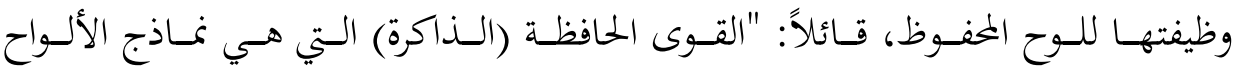

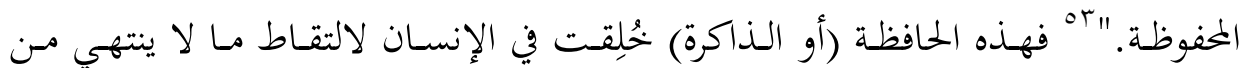

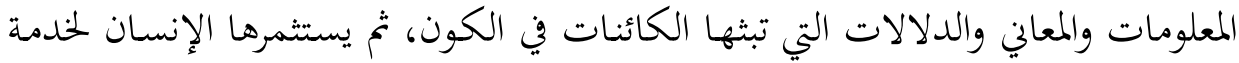
مصالحه، وتشييد صرح عمرانه وَفق العلاقات التي تربط بـين هـذه الكائنـات والقـوانين المنظمة لها.

أمَّا الكلية الثانية فتـل على أنَّ الكائنات جميلها وقبيحها، خيرهـا وشرها، إنَّا هي ابتلاءات وجودية تذيق الإنسان طعم الحلاوة والمرارة الدال بالقوة على وجود الجنة والنار

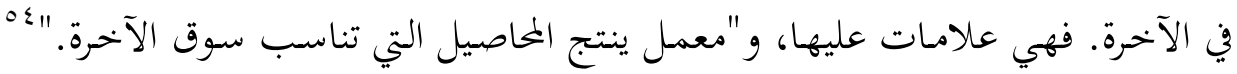

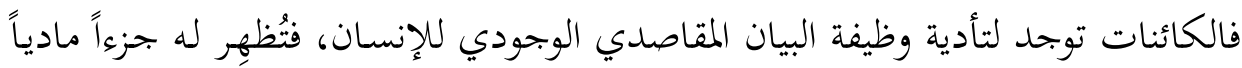

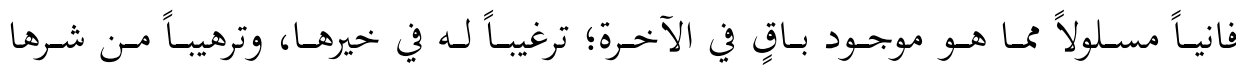

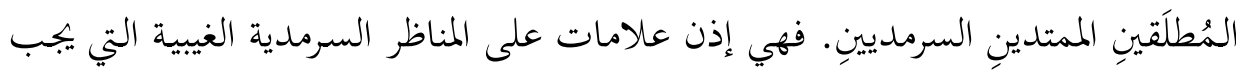

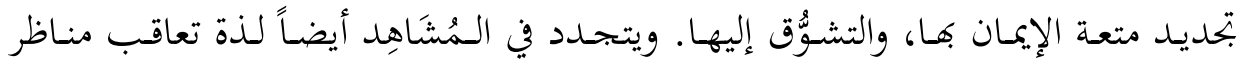

ro الغزالي، أبو حامد. تهافت الفلاسفة، قدَّم له وضبط نصه: أحمد شمس الدين، بيروت: دار الكتب العلمية، طا،

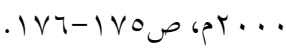

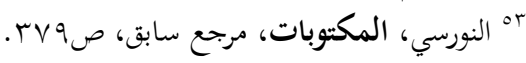

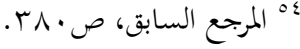




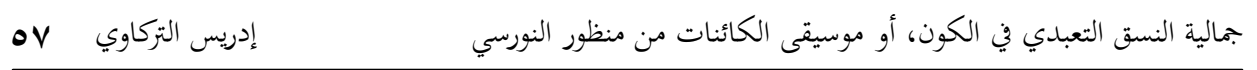

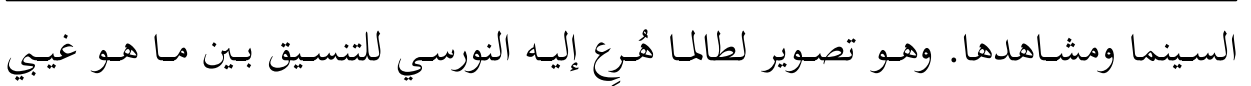

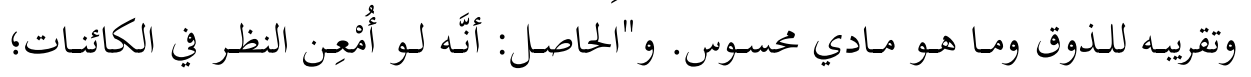

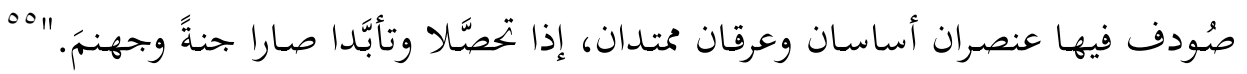

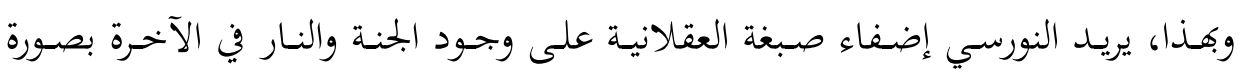

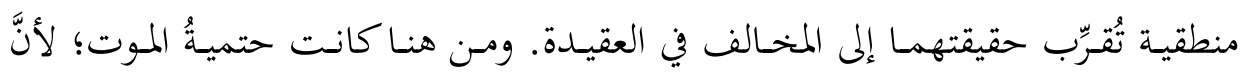

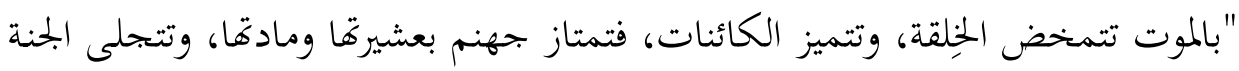

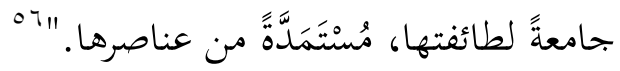

وأمَّا الكلية الثالثة فحقيقتها المضمرة وجـوب الإيمان بصفات الله تعالى المتنوعـة في

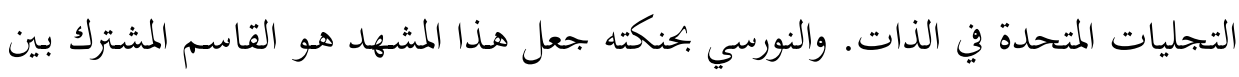

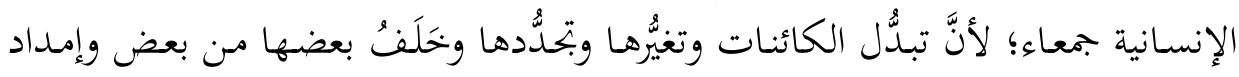

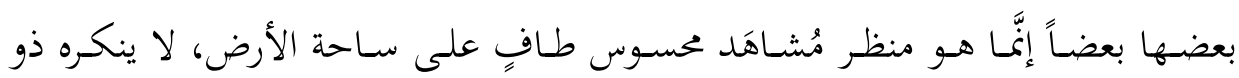

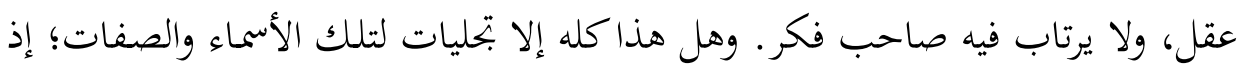

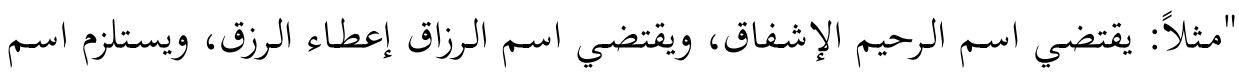

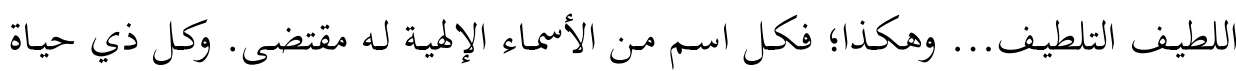

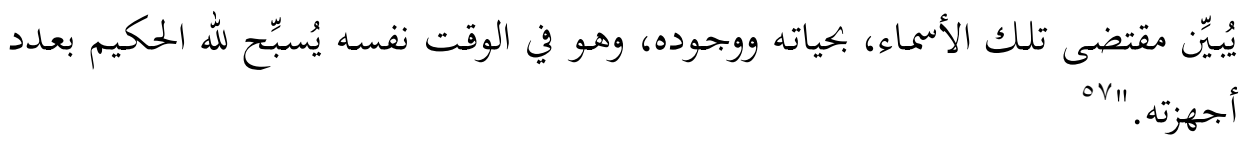

إذن، بمقتضى هذا التلازم بين الأسماء وبتحلياتها، وبمقتضى القانون المشترك بين النوع الإنساني في الإدراك؛ يلزم الإقرار بعظمة الربوبية والألوهية المتصفة بهذه الصفات ولمعات الجلالية

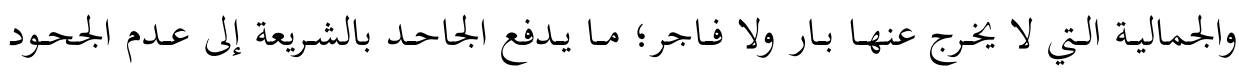

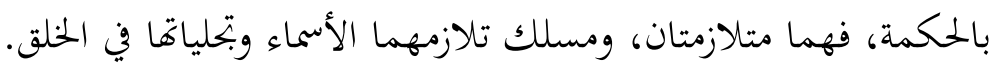

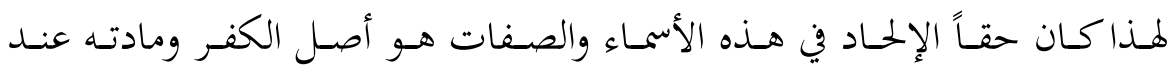

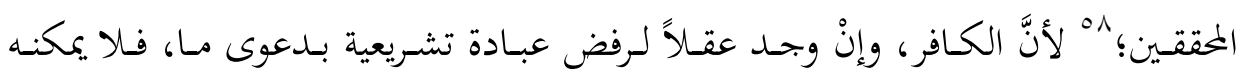

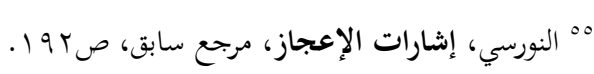

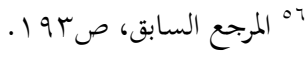

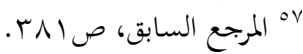

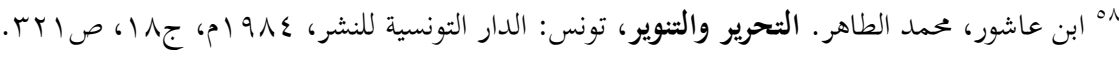




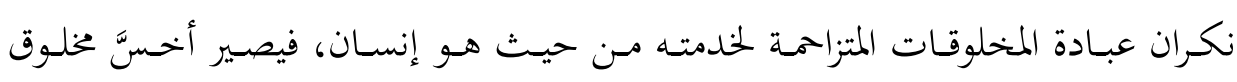

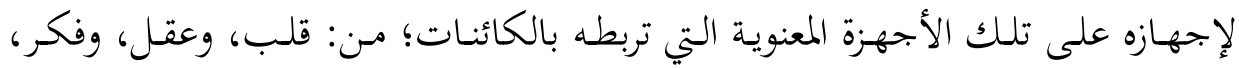

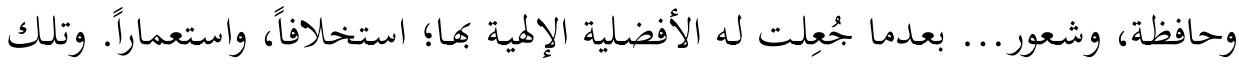

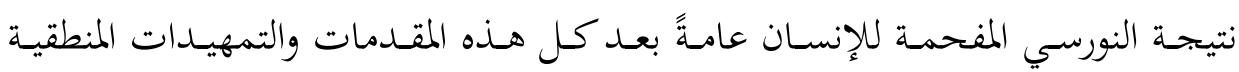

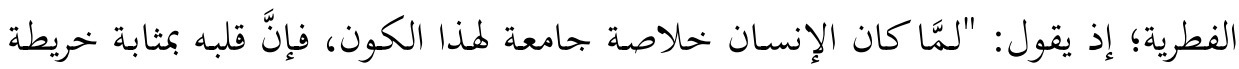

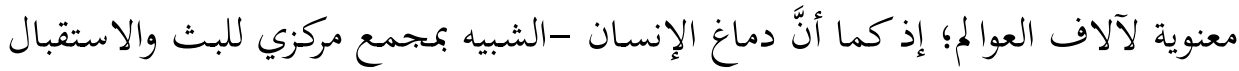

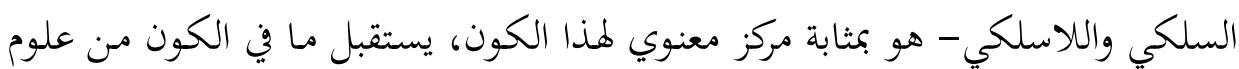

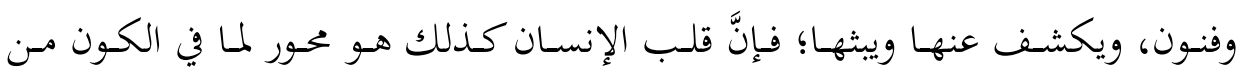

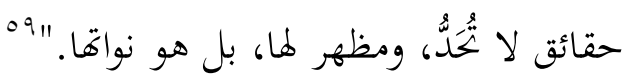

فهذه الكليات الثلاث متلازمة في أداء الوظائف والغايات والحِكَم. غير أنَّ محكها

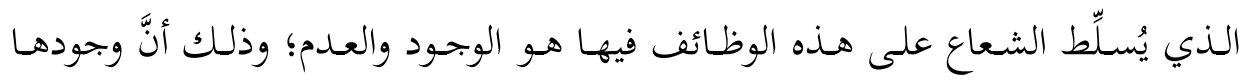

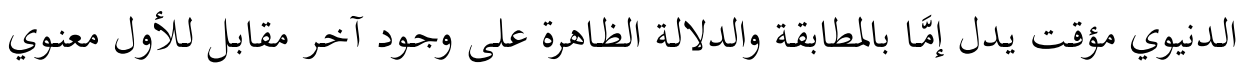

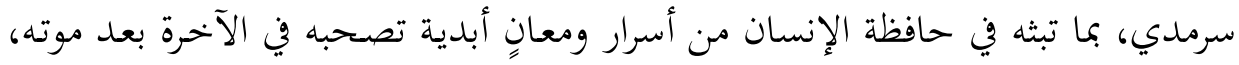

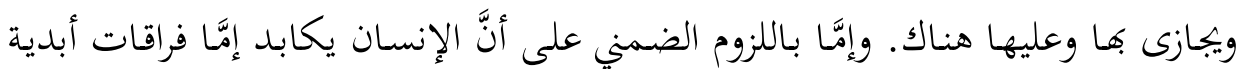

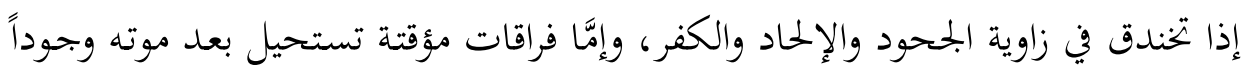

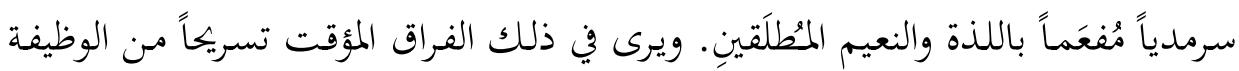

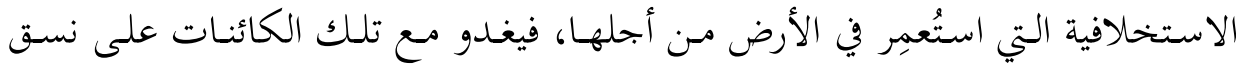

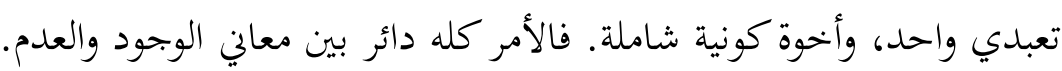

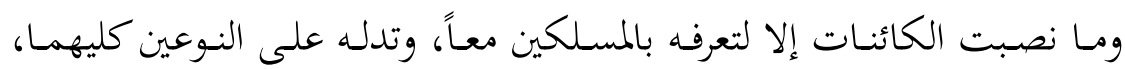

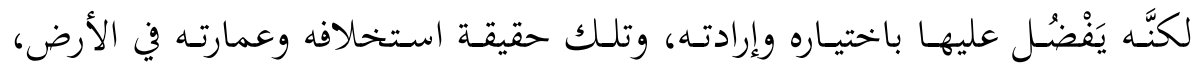

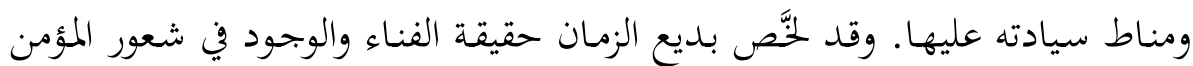

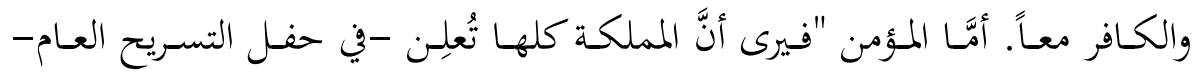

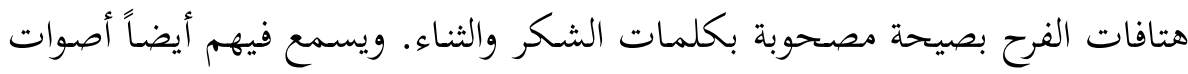


الجوقة الموسيقية وهي تُقـدِّم ألحاهـا الحماسية مقترنةً بـالتكبيرات العاليـة، والتهليلات

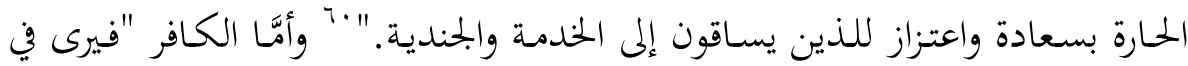

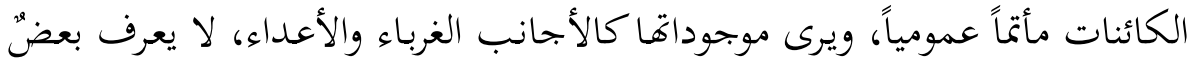
بعضاً، بل يعاديه، وترى جامداتا جنائز دهَّاشة، وترى حيواناقا وأناسيَّها أيتاماً باكين

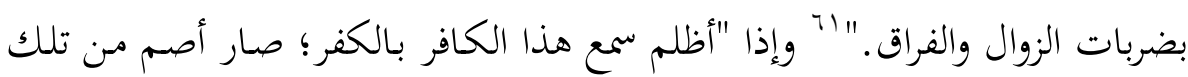

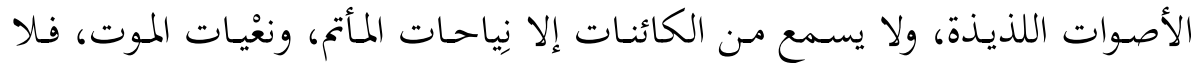

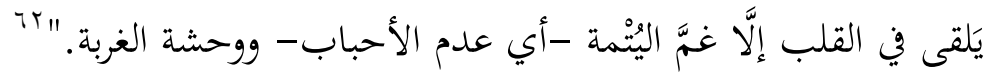

تلـك هي قصسة الفنـاء والوجـود للكائنـات والإنسـان جميعـاً، وهي النتيجـة الحتميـة الموضوعة نُصْب عقل كل إنسان ليتملَّى مشاهدها في الكون، عساه يؤوب إلى رشده من

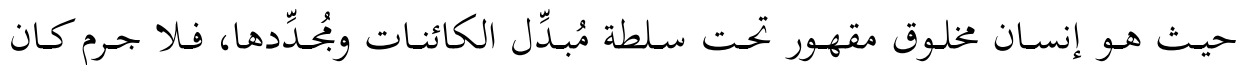
هـدف النورسي هـو احتضـان الإنسـان الغربي بعقلنته قوانين التكليف التعبـدي، وبيـان جذورها المنطقية الفطرية، وإنْ كانت تفاصيلها غيبية.

\section{ب. دلالة القرآن عليها:}

يُضمِر سياق هذه الكليات المقاصدية والوظائف التكوينية عند النورسي سؤالاً يُنِّبَ عن حُجيتها في القرآن الكريم بوصفه كشَّاف الحقائق، وفهرس الموجودات جميعها. ولهذا، يمكن للمعتبر أنْ يسأل: ما منزلة هذه الوظائف والمقاصد في كليات القرآن الكريح؟ لا يـألو النورسـي جهــاً في التنسـيق المنهجـي بــن حقيقـة القـرآن الكليـة ومنـزلة

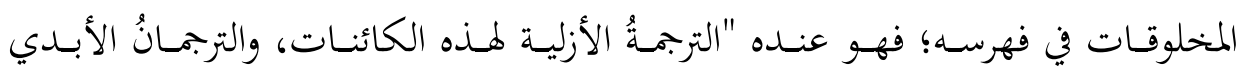

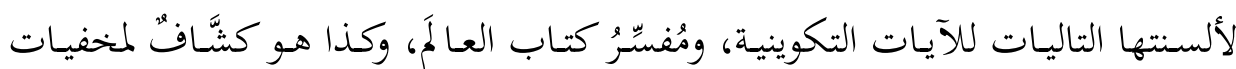
كنوز الأسماء المستترة في صحائف السموات والأرض."

$$
\begin{aligned}
& \text { "7 النورسي، الكلمات، مرجع سابق، ص. ـ ا. }
\end{aligned}
$$

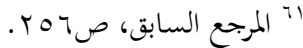

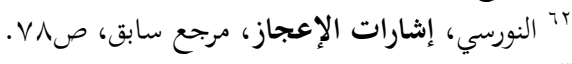

$$
\begin{aligned}
& \text { זי المرجع السابق، صبارك. }
\end{aligned}
$$


وهذا التعريف نفسه هو كليات منضودة في نسق وظيفي يتجاوب مع وظائف تلك

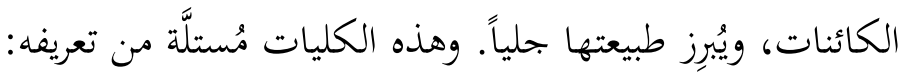
- كلية التعريف بالكائنات في امتدادها قبل خلقها (الأزل)، وبعد خلقها (الأبد)؛ أي كوها كلماتٍ، ثم حقائقَ وأجساماً. - كلية التسبيح والتعبد بألسنتها التالية للآيات التكوينية؛ أي للأوامر الإلهية القاضية بتكوينها والامتثال لها. - كلية الكشف عن معاني الأسماء والصفات وبتحلياتما. وأنتَ ترى أنَّ هذه الكليات متساوقة مع تلك الوظائف والطبائع عموماً. والنورسي هـذا التعريف إنَّا كان يروم نَظْم معاني النصوص القرآنية ودلالاتها ومقاصدها التكوينية

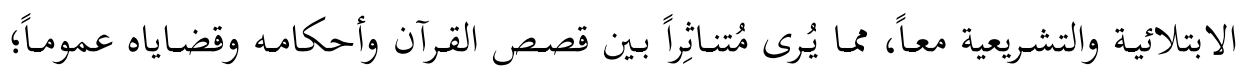

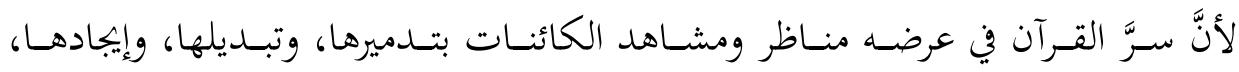

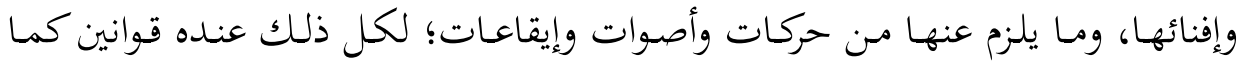

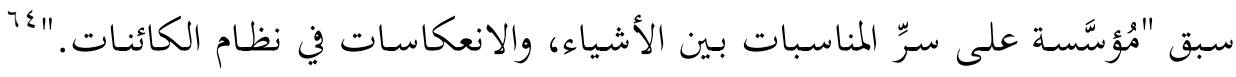

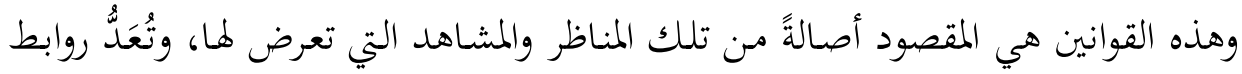

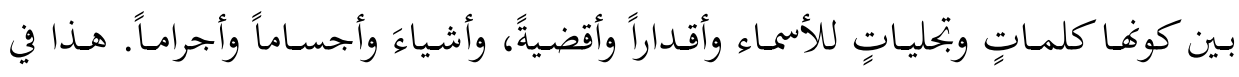

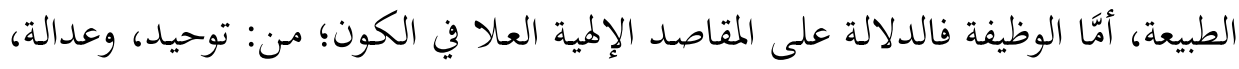

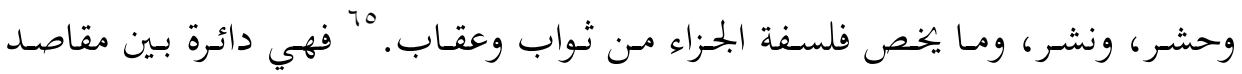
طبيعية لخدمة نفس الإنسان، ومقاصد تشريعية لجمسِّ نبض الروح فيه. ولهذا، بجد القرآن الكريم يعرض حقيقة الماء مثلاً، وما يُنبتهه مـن كائنات ومخلوقات

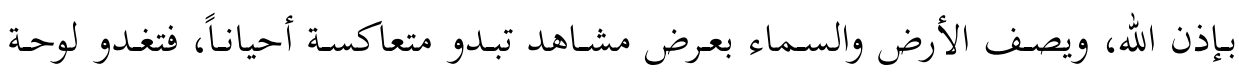

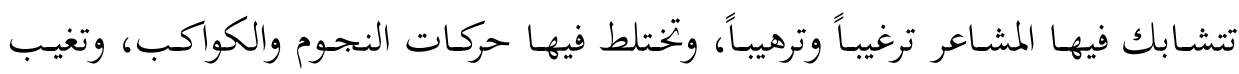

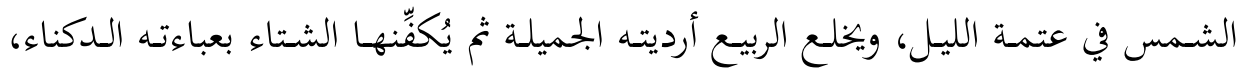

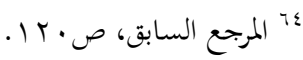

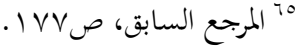




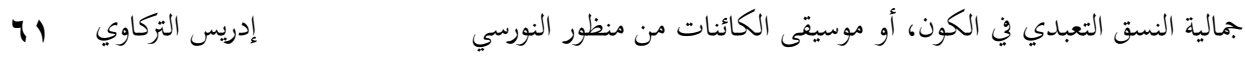
وتقضي الكائنات نحبها، وتستمر الحياة بولادة كائنات جديدة، وتستمر الطبيعة تترنح بين هيئات وكيفيات وصور وأعراض.

هـذه كلها وغيرهـا مشـاهد يعرضها القـرآن الكريم للتدبر، والتعريف بالخـالق، وبيـان

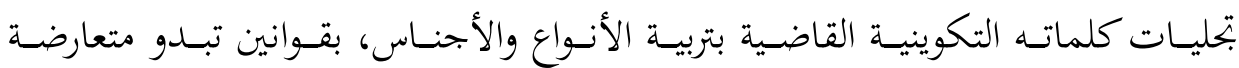
ومتناقضـة في المنطق البشـري النسبي، بحيـث يتـاخل فيها الخـير بالشـر، وتتمـازج فيها

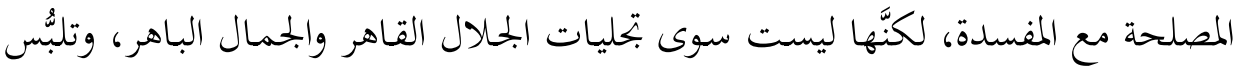
أحدهما بالآخر . والمقصود مـ هذا العرض استثارة قلب الإنسان طبعاً. يقول رحمه الله:

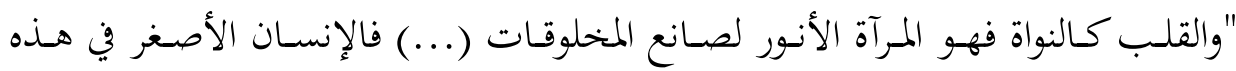

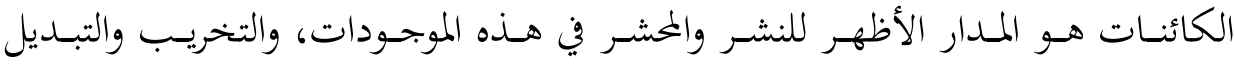

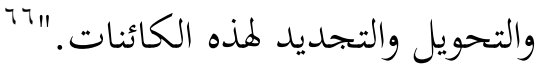

إذن، مشـاهد القرآن في الكـون منـاظر وأصهوات جميلة مُسيَّجة بـالجلال، تستثير في قلب الإنسان التسبيح كما تستثيره في سائر المخلوقات. ومن هنا، يمكن وصف آياته بما يشبه الترنم والعزف والموسيقى في نظر النورسي؛ إذ يقول: "إنَّ الله ينادي بقرآنه الكريم

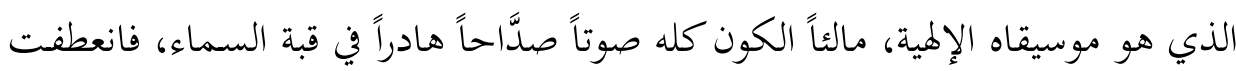

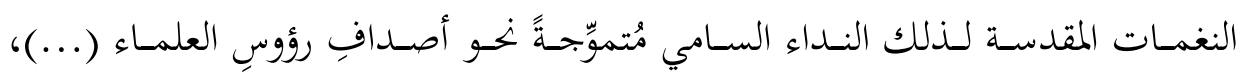

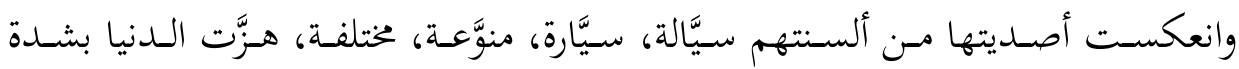

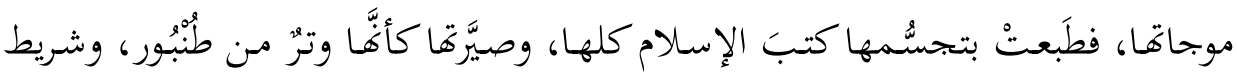

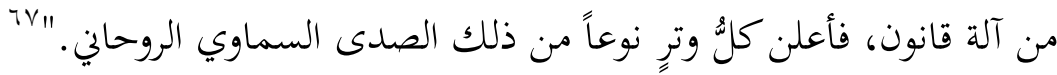
العلمـاء والبحتهـدون في ذوق النورسي ليسـت عقـولهم وقلـوبهم سـوى أجهزة رصـد

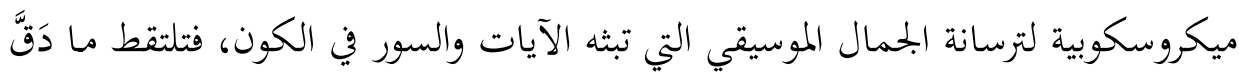
وخفي من الحكم والأسرار. وعلى قدر بحاوب القلب معها يتولَّد الإبداع ويتطور في جميع لئي

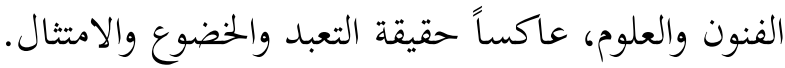


وعلى هـذا، وجـب أنْ تكـون موسيقى القرآن سـرمدية متـدة بأصواتما الجميلة التي

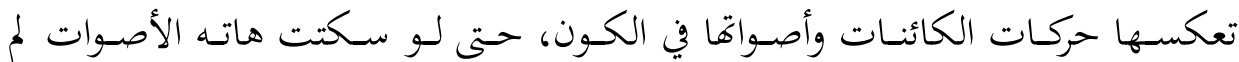

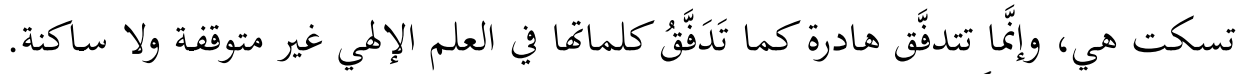

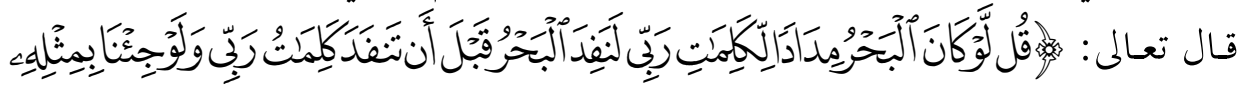

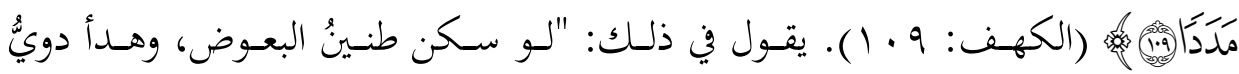
النحل فلا تأسوا، ولا تحزنوا، ولا تخمـد أشـواقكم أبـاً. فالموسيقى الإلهيـة العظيمـة التي

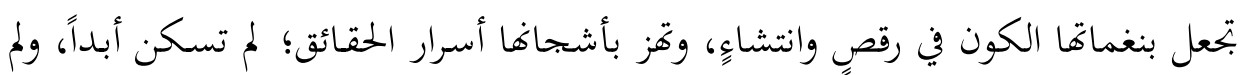

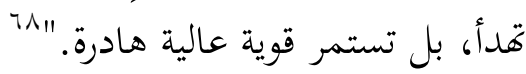

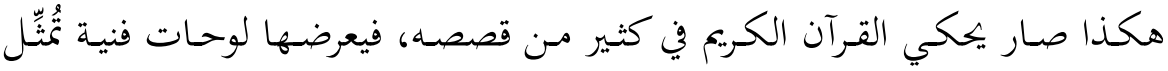

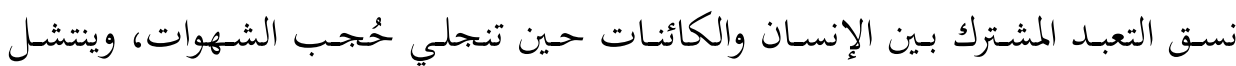
الإنسان نفسه من انغماسها المفرط في الاهتمامات الشخصية.

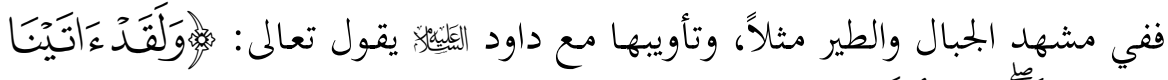

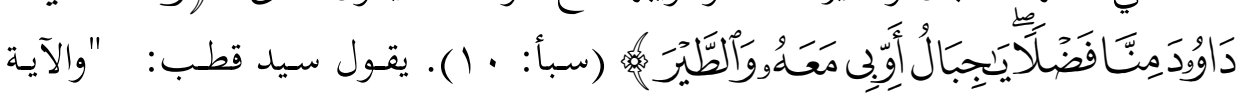

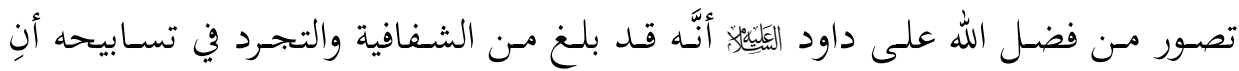
انزاحت الحُجب بينه وبين الكائنات، فاتصلت حقيقتها بحقيقته، في تسبيح بارئها وبارئه،

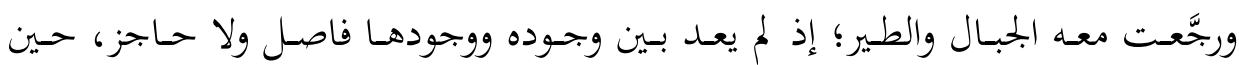

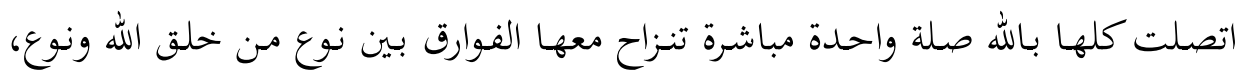

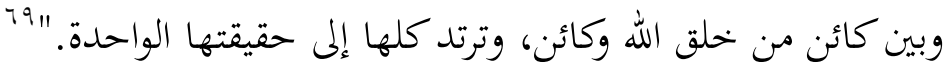
على شـاكلة هـا التصوير الفني وُضِع نسق التسبيح والذكر في الكائنات في سائر

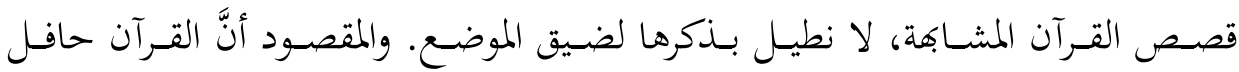
بالمشاهد المتلونة والمتباينة في الطبيعة والإنسان، التي ترسو سفينتها في فاية المطاف على لمرك ضفة النسق التعبدي، القاضي بالتسبيح والذكر والشكر للصانع، وبيان مقاصد الإنسان الوجودية؛ من: موت، وحشر، ونشر، وجنة، ونار.

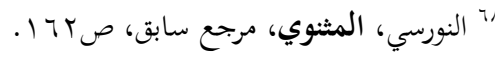

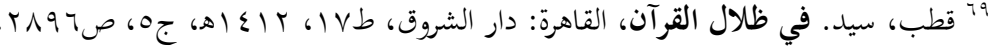




\section{رابعاً: المتقابلات مسرح الجمال التعبدي المُفعَم بالتسبيح}

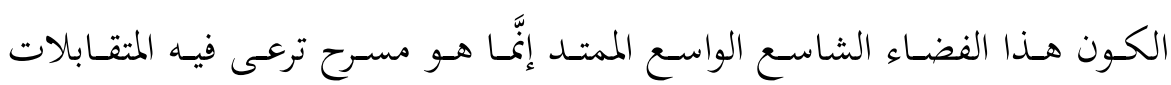

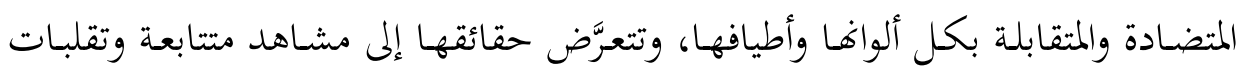

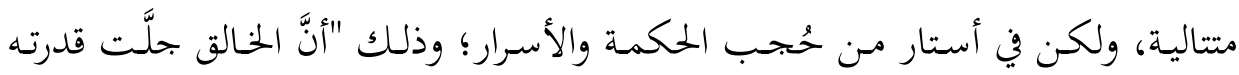
مزج الأضداد في عالم الكون والفساد لِِِكَم دقيقة، ووضع أسباباً ظاهريةً ووسائطَ؛ إظهاراً

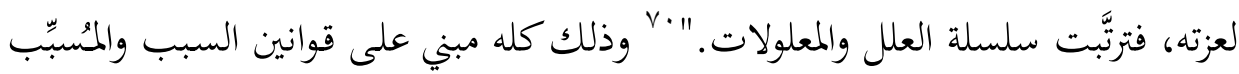

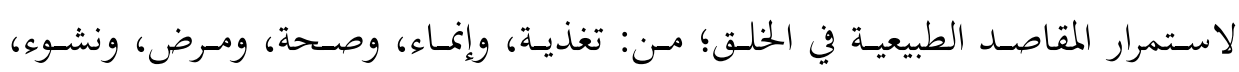

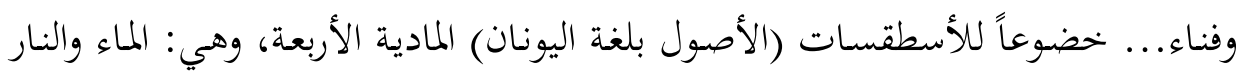

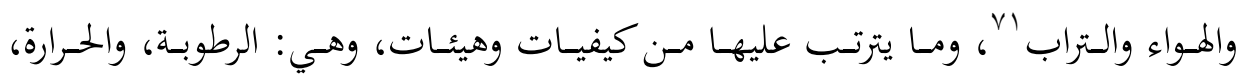

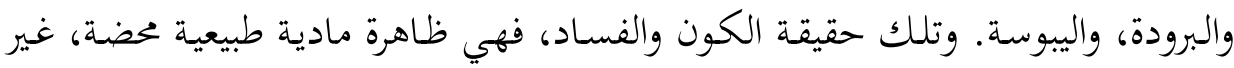

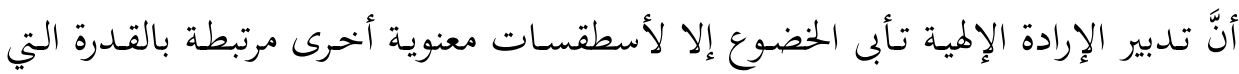

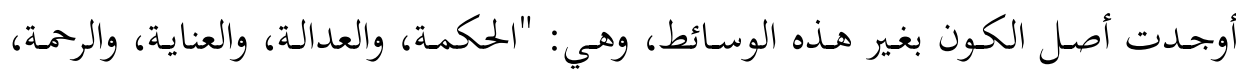

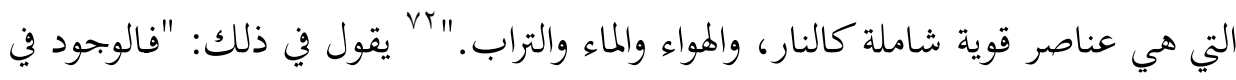

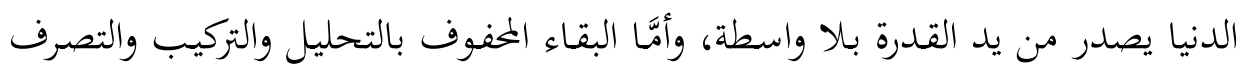

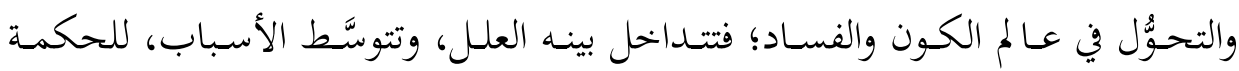
المذكورة سابقاً." المجول في عالم

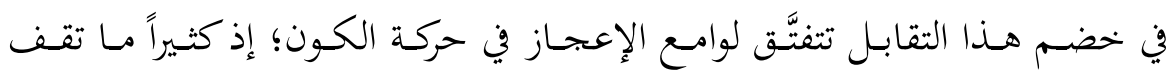

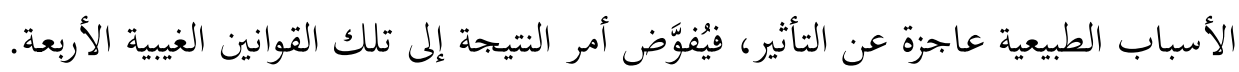

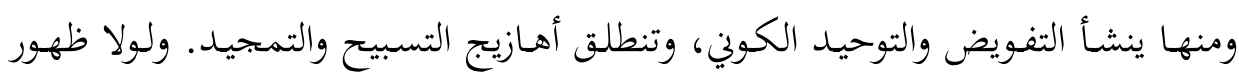

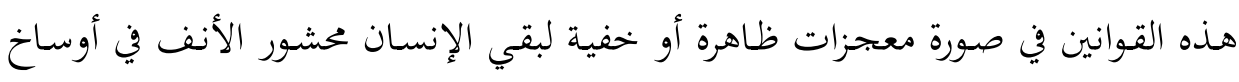

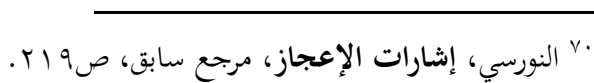

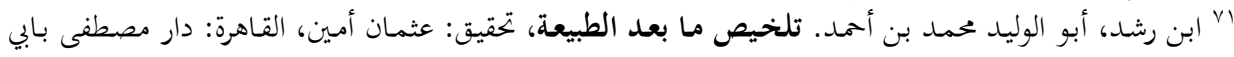

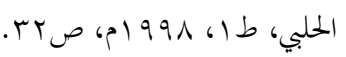

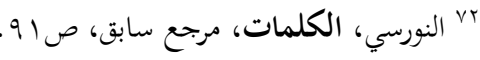

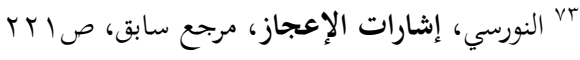




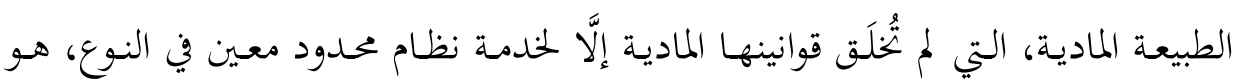

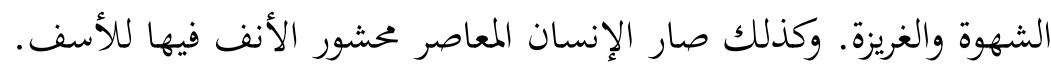

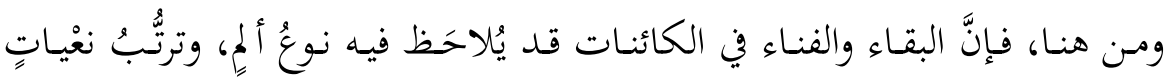

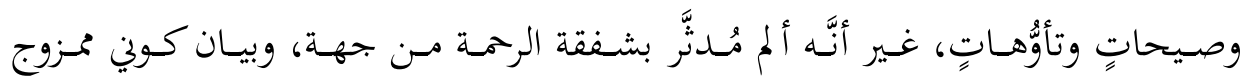

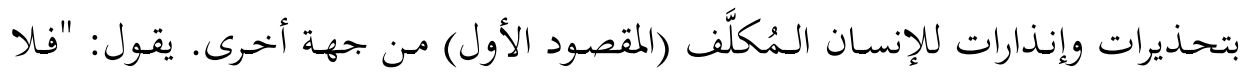

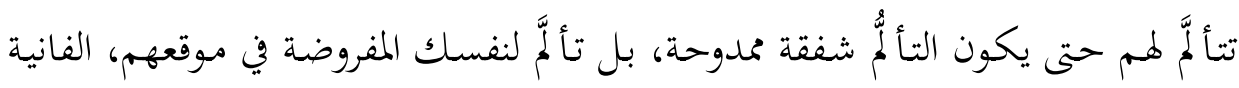

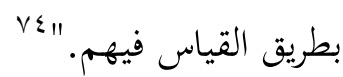

مـن تم، فقـد سـيقت أعمـال كثـير مـن الطيـور والحشـرات وغيرهـا، لرصــ وظــائف

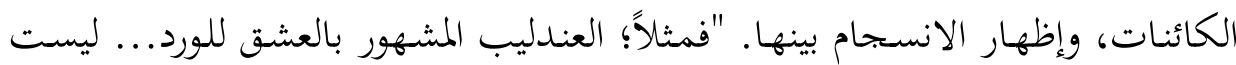

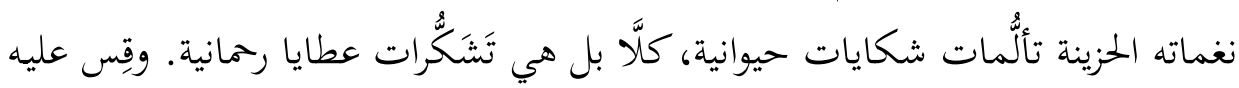

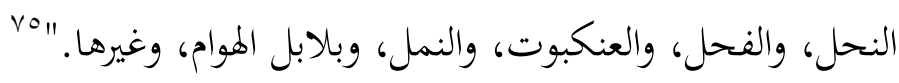

صوت العندليب ونهيبه يوحي بمعاناته وتألُّمه مثل صوت عواصف الرياح وجلجلة

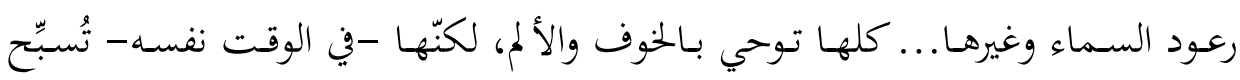

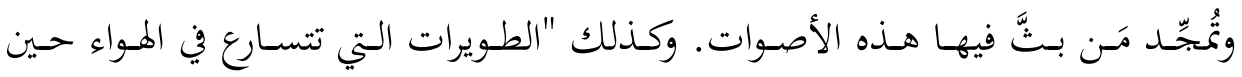

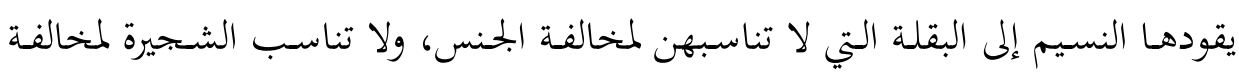

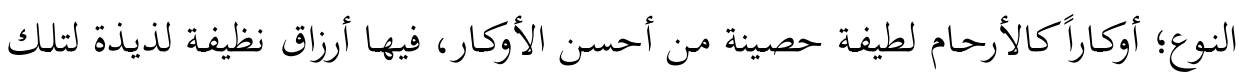

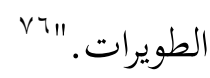

والمقصـود أنَّ تقابُل النوع والجـنس وتضـادها في الطبيعة هـو عـين التراحم والتواصل

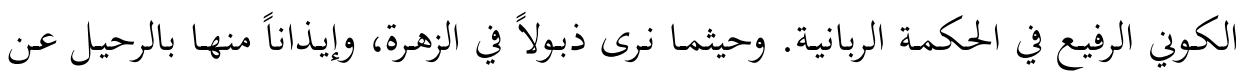

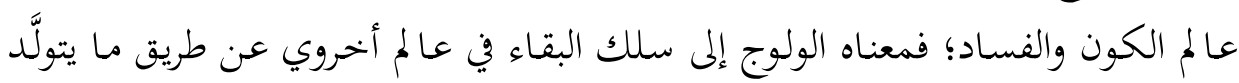
عنهـا مسن دلالات ومعـانٍ وماهيـات وهويـات للأشسياء في ذاكـرة الإنسـان، وفي اللـوح

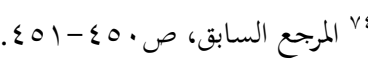

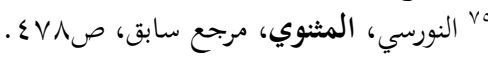

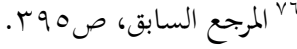




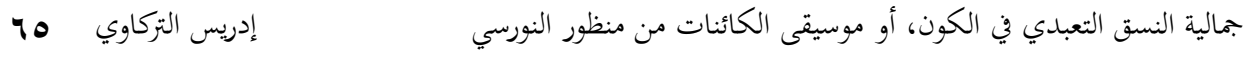

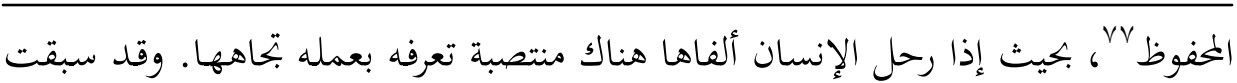
الإشارة إلى ذلك.

إنَّ ألم الزوال والرحيل للكائنـات ومشـاهدها الجمالية الطبيعية إنَّا هـو بسبب فراق اللذة والمتعة التي رحلت برحيل حاملها وجوهره. بيد أنَّ لزينة الإيمان وجماله يداً بيضاءً إنهاء تكشف الغطلاء عن حقيقـة المحسوسـات ومرجعها، فيبدو جـلال الربوبية يغطي خشبة

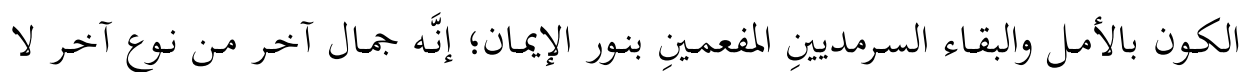

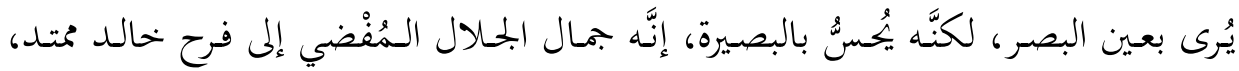

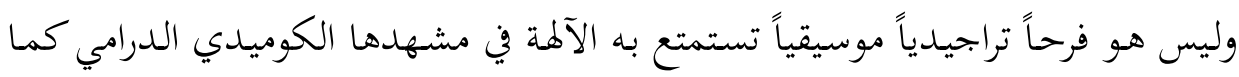
تُصوّره الأجناس الأدبية الغربية التي تقتات من التصورات المسيحية للفن والحياة، في حين

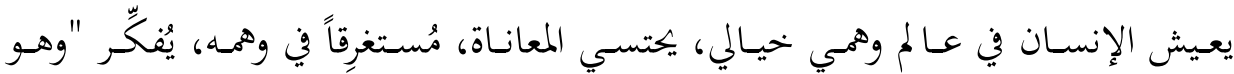

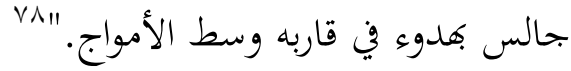

ليس الأمر هكذا في الفلسفة الإسلامية القرآنية؛ لأنَّ الله الواحد مُنزَّه في عليائه عن

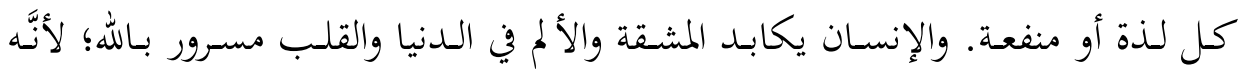
تكليف إلهي مُفعَم بأشعة الأنس بأسماء الله وصفاته وأفعاله.

فالرؤية السارَّة هي الإيمان بالبقاء الحقيقي المُفعَم بالجمال والجحلال، لا وهـم موسيقي

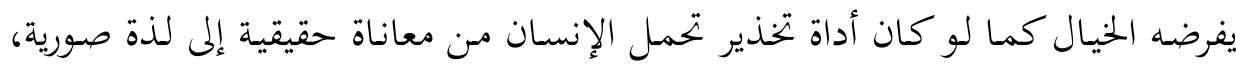
فلا يلبث حتى يجد نفسه في عالم ملؤه نفس ما حاول الفرار منه. إنَّ رحلة الحروب والمقاساة والفراقات الأبدية التي تُبديها حركة الكون والكائنات إنَّا هي ابتلاء ينتهي بـالموت. والمـوت هنـا بدايـة تسريح الوظيفـة الابتلائيـة، ودخهول المتعـة

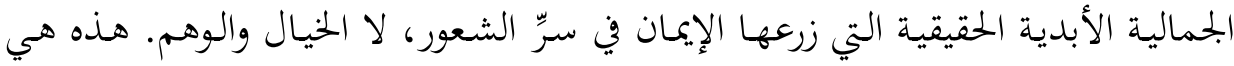
الفكرة العامة التي تحاول الكائنات جاهـدةً الاستدلال عليها، بتناسقها، وتعاوهـا، وأداء

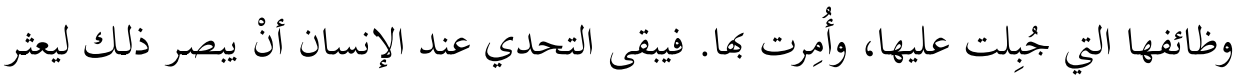

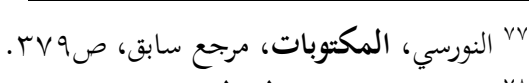

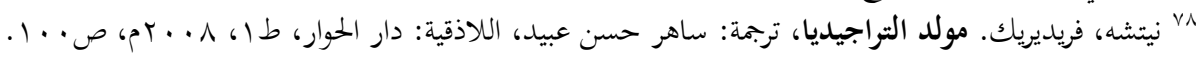




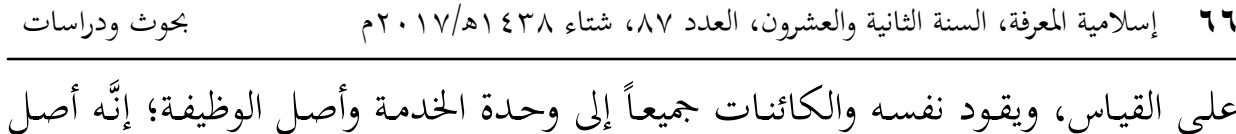

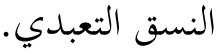

\section{خامساً: من تداعيات النظرية وامتداداتها}

\section{I ـ إنشاء فلسفة جمالية تعليمية راقية:}

لطالما اهتم النورسي بالنشء في رسائله، وأوصى بهم على قذر اهتمامه بإنشاء فلسفة جمالية، جذورها في الغيب والإيمان، وفروعها في مناهج العلوم الكونية والمادية. لقد كانت

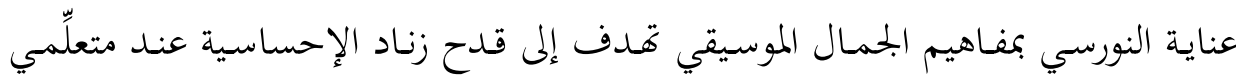

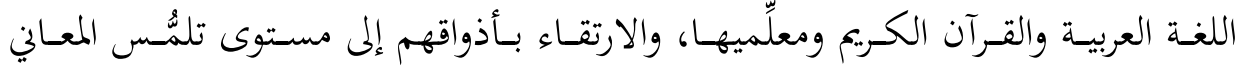

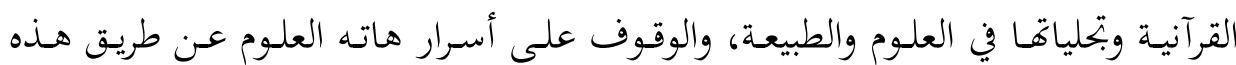

$$
\text { الكليات نفسها. }
$$

فهو لا يحبس العلوم الكونيـة والطبيعيـة في قمـاقم مقفلـة متقوقعـة على ذاتها، وإنَّا

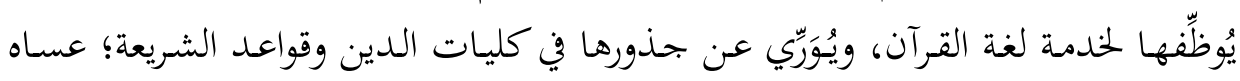

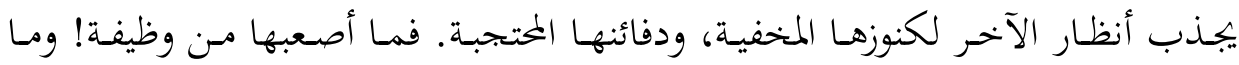

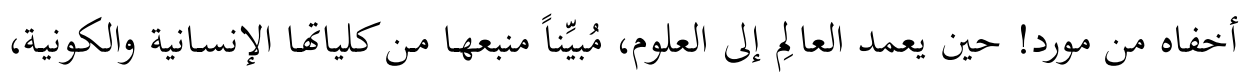

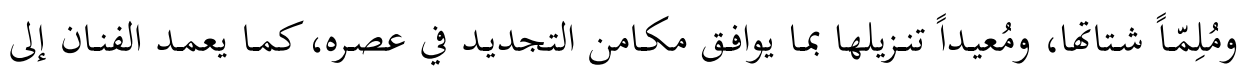

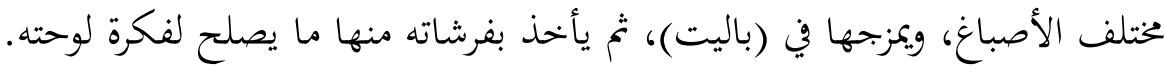
واليوم، ومـع تطور الآلهة، والركوع إلى الأشياء، أصبح كلهّ مـن الفن والجمـال يُنتَجج

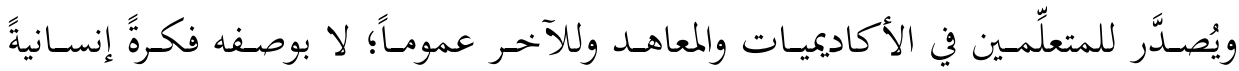

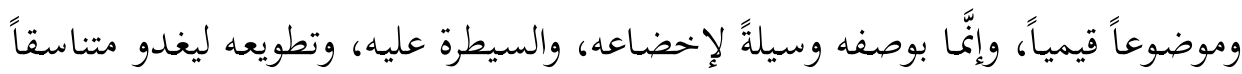

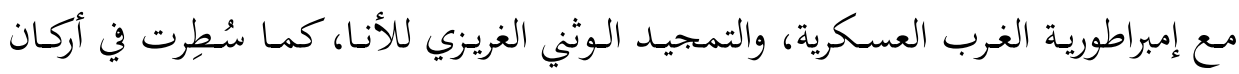

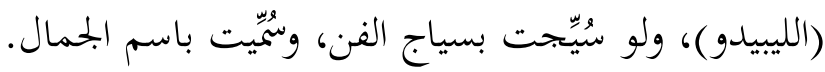
مـا زالـت الحـرب والفانتازيـا المبنيـة على ثنائيـة إخضـاع الضعيف للقـوي هي طـابع السينما والدراما في الغرب مثلاً... فأفلامه العملاقة هي التي بنحت فئ فيها فيها فكرة تصوير 


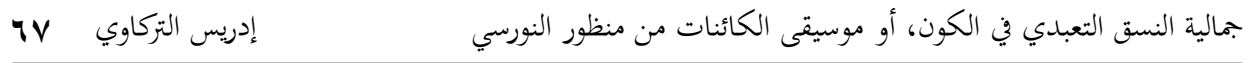

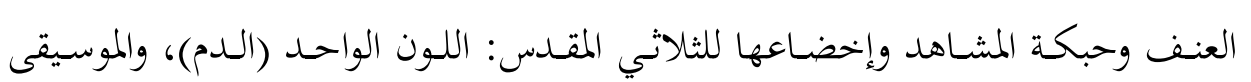

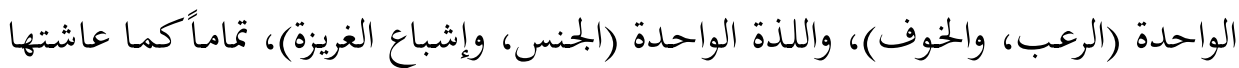

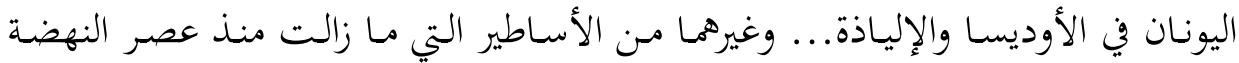
الأوروبية تنفث غبارها في المخيال الغربي، فيعيد إنتاجها في صورة أكثر تشؤهاً وبشاعةً. وفكرة السـلام أو الأمسن كفكـرة الجمـال؛ "لا تـرى السـلام إلا حيثمـا يكـون مُؤيَّداً بالسلاح." "va والفكرتان متآخيتان على كل حال.

\section{Y r. استثارة الإنسانية في الإنسان:}

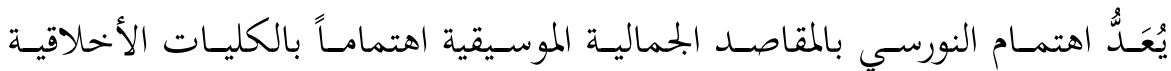

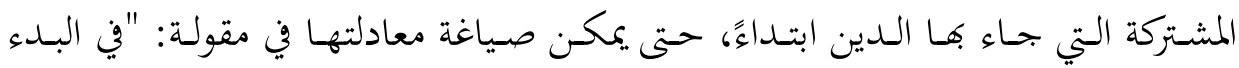
كانت الكليات" ... هكذا على سبيل الترجيح القطعي، مثل: الحياة، والعدالة، والعبادة، والتوحيد، والجمال.... وذلك لاستدعاء جميع الأجناس الكونية إلى بساط العبادة الكوني، والامتثال لسلطة الربوبية التي قضت بتكوينهم وخلقهم من حيث هـم مخلوقات، وبوصف

$$
\text { الإنسان نوعاً منها، داخحلاً في زمرتها. }
$$

إنَّهـ مـنهج القـرآن نفسه حسين يشحن قوالب خطابه الكامل بمعاني المشترك الكلي

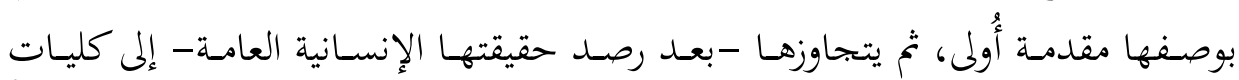

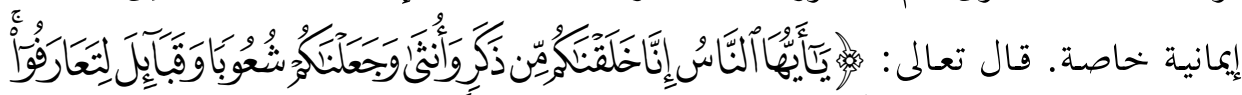

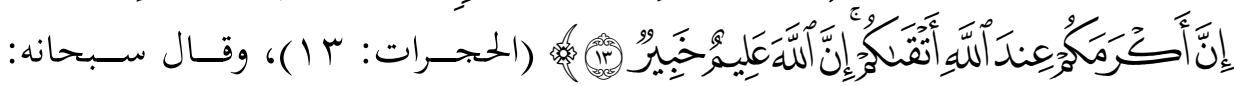

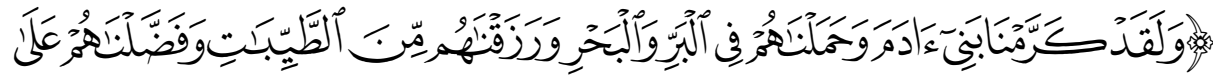

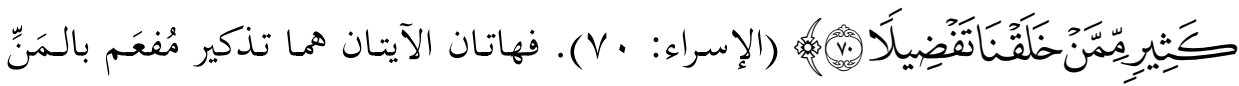

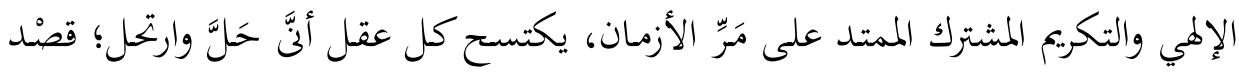

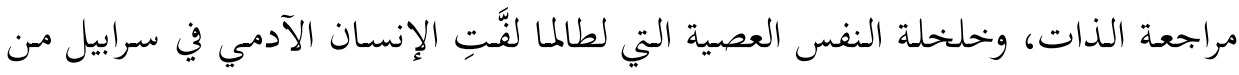
الشهوات حالت دون أَوْبَهِ وتذكُّره. 
ويشبه أنْ يكون تلاشي (أو قلَّة) هـذا الصدى الفطري في بواطن الخلق في العصر

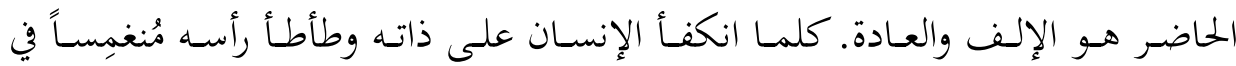

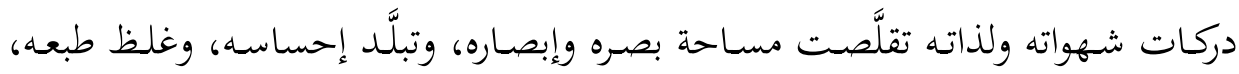

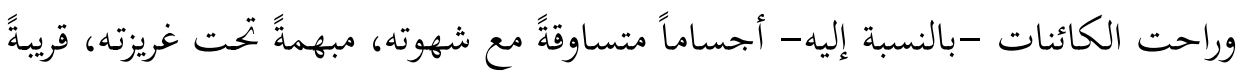
منه كقرب إصبعه من عينه، يكاد لا يبصره ولا يَعِيه. كذلك حقيقة المخلوقات إذا نظر مترك إليها بمنظار النفس.

مـن هنا، كان التدبر في هذه الكائنات صقالً للطبع، وتنظيفاً لمرآة النفس؛ عسـاها

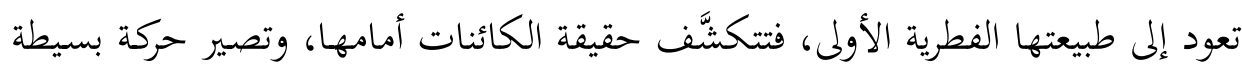

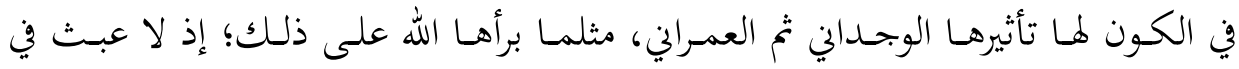

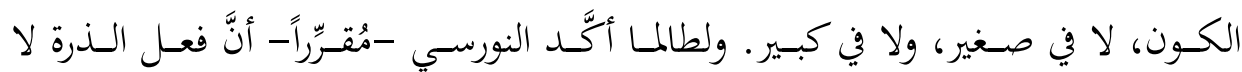

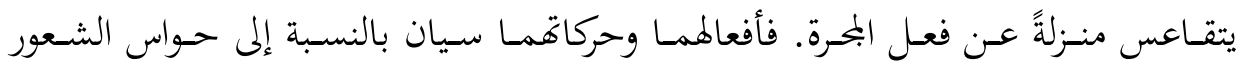

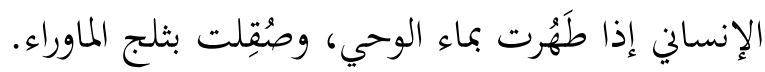

كذلك كانت نظرة عملاق الأناضـول إلى العـالم، قاصداً تأسيس فضـة تركية تَسَعُ شريط الأناضول، وتمتد لتغزو العالم بسلام وجمال يداعبان أركانه بلطف وسلاسة. وقد استجابت له الأقدار على نحوِ عجيب لافت؛ إذ باتت مراكز البحوث النورسية

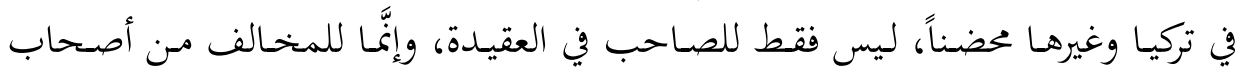

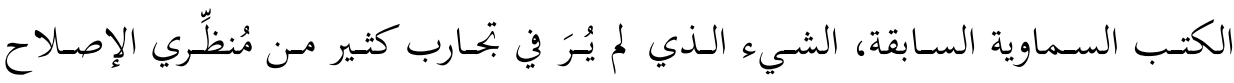
الحضاري.

خاتمة:

يوجد في الكون منظومتان مركزيتان تُمَّّلان جوهر الكائنات (الروح والمادة)، وتدفعاها إلى إفراز ألوان متجانسة ومتباينة من المقاصد التوحيدية والوظائف التسبيحية، تُعَدُّ مادة

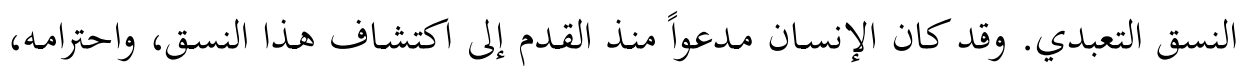




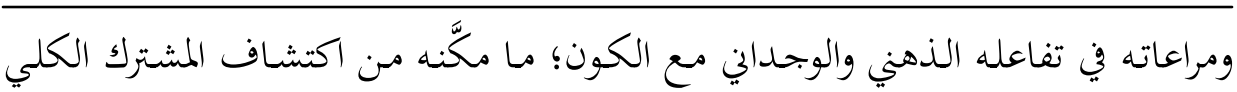
بين أفراده النوعية بوصفه إنساناً، وفي ارتباطه بسائر الأنواع بوصفه مخلوقاً كونياً.

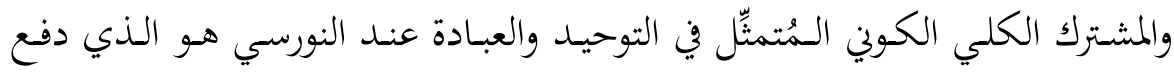

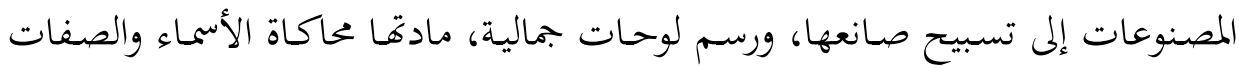

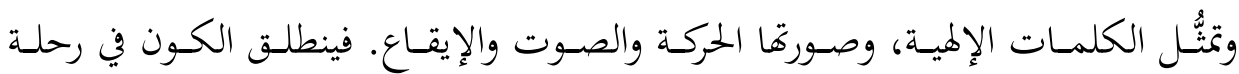

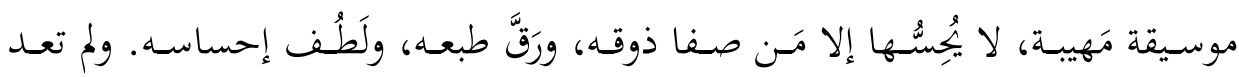

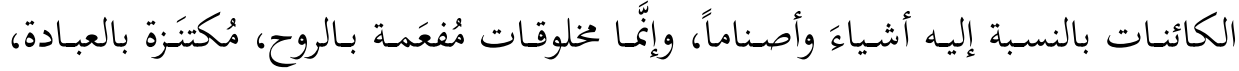

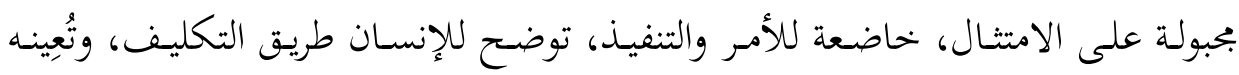

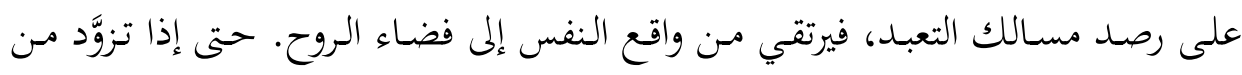

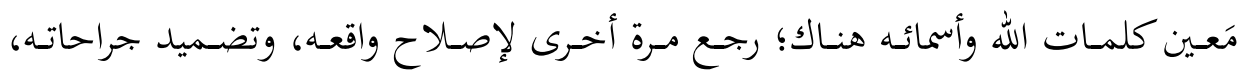

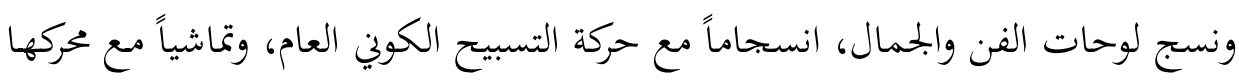

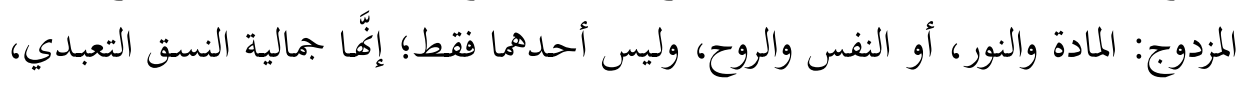
أو موسيقى الكائنات.

كذلك كان محور هذه الدراسة بوصفها مدخلاً آخرَ من مداخل قراءة التراث؛ قراءة

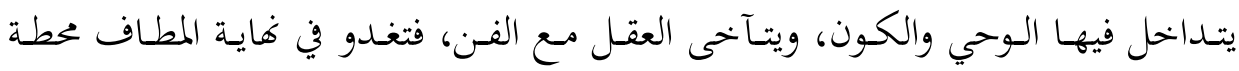
لتناسل قضايا وإشكالات قد يكون أهمها ما يأتي: - نظرية الجمال الكوني، وهي دراسة في كليات الجمال الكوني، ومظاهره، وعناصره كما هي في رسائل النورسي. - البحثث عن النستق الجمالي في العلوم الشـرعية عن طريق علم التصوف خاصةً، ببيان القنوات الحاملة لنظرية الجمال التعبدي في مباحثه. - البحثث عن النسق المقاصدي الذي ينظم قواعد العلوم، وينضد كلياهـا في عقد جامع، يسهل رصد معا لم الوحدة المنهجية التوحيدية فيها، والعثور على الأنموذج المعرين المشترك بينها. 